\title{
Habeas Corpus, Imperial Rendition, and the Rule of Law
}

\section{Michael Lobban*}

\begin{abstract}
In the decades which followed the publication of AV Dicey's Law of the Constitution, most English lawyers felt confident that the rights and liberties of Englishmen were protected by a rule of law, which was secured through ancient common law remedies such as the writ of habeas corpus. In their view, this ensured that no political activists would be detained without trial, unless there were particular emergencies which allowed the writ's suspension, in order to protect the very rule of law. At the same time that these arguments were being made, however, detention without trial became an increasingly routine feature of colonial governance. This article examines the attempts used by political detainees from different parts of the empire to challenge their rendition and detention, and explores what the judicial response tells us about perceptions of the rule of law in the era when Dicey's work was establishing itself as the classic text of constitutional law. Focusing on a number of key cases, it examines how courts examined two central issues in habeas corpus cases. The first concerns the legality of the detention. In discussing this issue, courts were presented with rival approaches to the rule of law, one which was more 'formalist' (asking whether the legislative instrument ordering the detention had a valid pedigree derived from the sovereign legislature), and another which was more 'substantive' (invoking a notion of fundamental rights). The second concerns the question of control, and explores the response of the courts to challenges to the writ by defendants who argued that they no longer had control over the detainee.
\end{abstract}

The writ of habeas corpus has long been held to be central to English notions of liberty and the rule of law. '[F]ounded on the broad basis of Magna Charta' (as Henry Hallam described it), ${ }^{1}$ it was seen by generations of nineteenth-century lawyers and historians as a vehicle to secure "the fundamental articles ... of the common law. ${ }^{2}$ It assumed a prominent position in the work of Albert Venn Dicey, who famously balanced an Austinian view of parliamentary sovereignty, according to which the formal validity of all laws had to be traced to a sovereign legislature, with a common lawyer's conception of the rule of law, according to which the substantive rights of

\footnotetext{
* Professor of Legal History, London School of Economics and Political Science. This article expands on some of the arguments I set out in "Habeas corpus et "rule of law" en Angleterre vers 1885-1914' (2014) 48 Revue d'Histore du XIX ${ }^{\mathrm{e}}$ siècle 77-91. Thanks also to the referees for their comments.

${ }^{1}$ Henry Hallam, View of the State of Europe during the Middle Ages (students' edn, William Smith (ed), J Murray 1871) 381-82.

${ }^{2}$ William Blackstone, Commentaries on the Laws of England (Clarendon Press 1765-69) 4:431; George Bowyer, Commentaries on the Constitutional Law of England (2nd edn, Owen Richards 1846) 418; ES Creasy, The Rise and Progress of the English Constitution (4th edn, Richard Bentley 1858) 149 n; TE May, The Constitutional History of England since the Accession of George the Third (2nd edn, Longman Green 1865) 2:254.
} 
Englishmen were the product of the ordinary decisions of courts applying their remedies to concrete cases. In his view, habeas corpus was one of the common law's primary tools to ensure that those in government were always subject to the rule of law. With its roots deep in history, it encapsulated what was unique about English liberty, for this common law remedy was a far more reliable tool to secure individual freedom than any abstract definition - more significant even than 'the celebrated thirty ninth article of the Magna Carta'. ${ }^{3}$ The judiciary also acknowledged that the writ had a special status. In 1890, in Cox v Hakes, the House of Lords held that there could be no appeal against the liberation of a prisoner under a writ of habeas corpus, despite the fact that the wording of the Judicature Act of 1873 suggested the contrary. As Lord Halsbury explained, the legislation had to be crystal clear before the judges would interpret it as removing 'one of the most important safeguards of the liberty of the subject.'

By 1885, when Dicey's Law of the Constitution was published, most members of the British political nation shared his confidence that the ancient heritage of English liberty was securely anchored in modern law. This was an era of social peace and widening political participation in England. Habeas corpus had not been suspended since $1818,{ }^{5}$ nor - until the outbreak of the Great War - were there any English political prisoners whom the government wanted to detain without charge. ${ }^{6}$ If habeas corpus was a guarantee of people's liberty against tyranny, it was one which never needed actually to be invoked against the government. For those of a Whiggish persuasion, the last political cause célèbre in England involving habeas corpus were the cases of the prisoners from Upper Canada and Lower Canada, who were detained for deportation after the two rebellions in $1837 .^{7}$ These cases had seen the rule of law vindicated by Lord Brougham, Joseph Hume, and JA Roebuck, when they thwarted the government's attempts to remove rebels from the provinces without putting them on trial. In Lower Canada, the authorities had issued an

${ }^{3}$ AV Dicey, Lectures Introductory to the Law of the Constitution (The Oxford Edition of Dicey, JWF Allison (ed), OUP 2013) 122.

${ }^{4}$ Cox v Hakes (1890) 15 App Cas 506, 514. A different rule applied in colonial cases, where there could be an appeal to the Privy Council against the liberation of prisoners: A-G Hong Kong v Kwok-a-Sing (1873) LR 5 PC 179.

${ }^{5}$ Habeas Corpus suspension acts had been passed in 1794-95, 1798-1801, and 1817 allowing the detention without trial of radical agitators. On earlier suspensions, see Paul D Halliday, Habeas Corpus: from England to Empire (Harvard UP 2010) 34, 247-56. On suspensions during the American revolution, see Amanda Tyler, 'Habeas Corpus and the American Revolution' (2015) 103 California L Rev (forthcoming).

${ }^{6}$ During the thirty years that Dicey himself continued to edit his classic text, writs of habeas corpus were regularly sought in England, but primarily in family disputes over the custody of children, rather than in politically sensitive cases. There were a number of controversial cases in the 1870 s and 1880s involving ritualist priests who were imprisoned after refusing to accept the jurisdiction of ecclesiastical courts: see Hudson v Tooth (1877) LR 2 PD 125; Hudson v Tooth (1877) 3 QBD 46; Ex parte Green (1881) 7 QBD 273; Sidney Faithorne Green v Lord Penzance (1881) 6 App Cas 657; Ex parte James Bell Cox (1887) 19 QBD 307; Cox v Hakes (1890) 15 App Cas 506.

${ }^{7}$ See the articles on Habeas Corpus by NW Sibley and JA Howard Watson in 67 (1923) 67 Solicitor's Journal 573 and 614. 
ordinance to transport eight men to Bermuda, ${ }^{8}$ while in Upper Canada, legislation was passed to empower the executive to grant pardons before trial to those charged with treason, conditional on their being transported to a penal colony. ${ }^{9}$ Brougham's parliamentary attack forced the government to concede that the Bermuda ordinance was unlawful and to disallow it. By contrast, the Upper Canadian legislation remained in place, and the rebels were removed from the province. However, on their arrival in Liverpool, en route to Van Diemen's Land, Hume and Roebuck sought habeas corpus applications on their behalf. Although both the Queen's Bench and Exchequer held that the men were lawfully detained in custody - since they were accused of treason - they did not resolve the disputed question whether the crown had any legal power to transport them to Van Diemen's land in the absence of a conviction and sentence. The government's lawyers soon realised they had no such power: faced with the choice of putting them on trial for treason in England or letting them go, the government took the second option. ${ }^{10}$ If the case of the Canadian prisoners seemed to show that the rule of law was a cultural value which needed men of political principle (like Brougham or Hume) to vindicate it, it also showed that once the law was put into motion, it could constrain even governments to whom the judges were favourably disposed.

Englishmen of Dicey's generation were of course aware that coercion had been used on a number of occasions beyond these shores, when the right to habeas corpus had been removed. The 1865 rebellion in Jamaica, which had been so brutally suppressed by Governor Eyre after his proclamation of martial law, had generated a profound debate in the metropolis about the nature of prerogative powers and the rule of law at times of emergency. ${ }^{11}$ Closer to home, Ireland had seen habeas corpus suspended on a number of occasions in the reign of Victoria. ${ }^{12}$ Only four

${ }^{8}$ An ordinance to provide for the security of the province of Lower Canada (2 Vic c 1 - 2nd sess) reprinted in F Murray Greenwood and Barry Wright (eds), Canadian State Trials, vol. II (Osgoode Society 2002) 480-83. It further provided that if any of them were to return to the province without permission, they should be deemed to be guilty of high treason and suffer the death penalty. See Jean-Marie Fecteau, "This Ultimate Resource": Martial law and State repression in Lower Canada, 1837-8' and Steven Watt, 'State Trial by Legislature: the Special Council of Lower Canada, 1838-41', in Greenwood and Wright, Canadian State Trials 207-47 and 248-78.

9 1 Vic c 10: 'An Act to enable the government of this province to extend a conditional pardon in certain cases to persons who have been concerned in the late insurrection'.

${ }^{10}$ Alfred A Fry, Report of the Case of the Canadian Prisoners with a Introduction of the writ of Habeas Corpus (A Maxwell 1839), The Canadian Prisoners' Case (1839) 3 ST NS 963, In the matter of Parker (the Case of the Canadian Prisoners) (1839) 5 M \& W 32. See also despatch from Normanby to Sir George Arthur, 23 July 1839 in Canada: Correspondence relative to the Affairs of Canada PP 1840 [221] XXXI. 219, 221 and more generally Cassandra Pybus, 'Patriot Exiles in Van Diemen's Land' in Greenwood and Wright (n 8) 190-92.

${ }^{11}$ See RW Kostal, A Jurisprudence of Power: Victorian Empire and the Rule of Law (OUP 2005).

${ }^{12}$ In July 1848, at the time of the Young Ireland rising, about 120 were detained under 11 \& 12 Vic c 35. The legislation was renewed in 1849: see the Lord Lieutenant's letter requesting an extension in The Times (London) 6 February 1849, p 5. Habeas corpus was suspended again in 
years before Dicey's book was published, a Coercion Act gave the Lord Lieutenant of Ireland wide powers of detention without trial. ${ }^{13}$ However, thinkers like Dicey did not feel that the rule of law was undermined by the occasional need for extraordinary powers, for those who exercised such powers could only do so within a framework of laws, ultimately set by a sovereign parliament - a parliament which could be trusted to confer them only when the rule of law itself was under threat. ${ }^{14}$ The fact that habeas corpus could only be suspended through a proper parliamentary procedure was demonstrated vividly in 1881, when Lord Redesdale suggested - at a time when Irish Nationalist MPs were blocking the passage of the coercion bill - that an act of 'constitutional despotism' was needed, whereby both Houses of Parliament would simply give a first reading to the bill, which could then be acted on by the executive in the certainty that an Indemnity Act would be passed in due course. This suggestion was rebuffed by the Lord Chancellor, Selborne, who pointed out that it would immediately involve the government 'in a contest with the Courts of Law, and with every Judge of every Superior Court in the country', since they would be duty bound to free any detainee who sought a writ of habeas corpus. ${ }^{15}$ The formal principle of the rule of law ensured that no official could interfere with a person's liberty, unless he had clear legal authority to do so, while the substantive values which underpinned the ancient English common law were regarded as safe in the hands of the British parliament.

This grand narrative served to sustain a claim that England remained, at its core and in its exceptions, faithful to the principle of the rule of law and fundamental liberties dating back since time immemorial. However, if it was a persuasive narrative for those in the metropolis of the British empire, it may have looked less convincing at the peripheries. While legislation infringing liberty was a rarity in fin-de-siècle England, it was much more routine in the wider empire on which the sun never set. The same era that saw coercion measures in Ireland also saw numerous ordinances issued in West Africa for the detention and deportation of specific political

1866, in response to an anticipated Fenian uprising: $29 \& 30$ Vic c 1 . The Act passed in 24 hours, with only six opponents. By the end of November 1866, 752 had been detained: Parl Debs 3rd ser, vol 185, col 733. Following another Fenian uprising, the act was extended first to March 1868 (30 Vict c 25) and then to March 1869 (31 Vict c 7).

${ }^{13}$ An Act for the better Protection of Person and Property in Ireland 1881 (44 Vict c 4). Ireland had a long history of Coercion Acts: see eg the Peace Preservation (Ireland) 1870 (33 Vict c 9); Protection of Life and Property (Ireland) Act 1871 (34 Vict c 25).

${ }^{14}$ Similarly, Dicey argued that there was no such thing as 'martial law' in England, under which military authorities could confer distinct powers on themselves by declaring a state of siege. Rather, the common law courts could always test whether those suppressing disorder had done more than was necessary. For Dicey, 'no more splendid assertion of the supremacy of the law' could be found than the 'protection' given to Wolfe Tone by the Irish Bench, when that court ordered him to be released on a habeas corpus after his conviction for treason by a military court. Dicey (n 3) 164. Given that Wolfe Tone had already cut his throat when the case was brought, and would die soon after, JWF Allison points out that this protection was largely formal and that Dicey's celebration was of 'the rule of law in all its skeletal formality': The English Historical Constitution: Continuity, Change and European Effects (CUP 2007) 161.

${ }^{15}$ Parl Debs 3rd ser, vol 257, col 825. Thanks to obstruction by the Irish members of parliament, it took until the end of March for the measure to pass. 
prisoners. ${ }^{16}$ Such legislation became extremely common throughout the empire, ${ }^{17}$ for a standard response of imperial administrators faced with troublesome local political activists was to remove them to another location where they would cause less trouble. ${ }^{18}$ This raised questions about the nature of the rule of law: was it simply a formal principle, to check whether officials had acted under powers whose validity could be traced to an authoritative source, or did it embody substantive principles inherent in the common law, about what kind of powers could be conferred on officials?

Such questions were only rarely discussed by judges in the metropolis, for although the Queen's Bench had jurisdiction to issue writs of habeas corpus to 'all parts of the Queen's dominions' at common law, ${ }^{19}$ legislation in 1862 had provided that no writ of habeas corpus would issue out of England to any colony or foreign dominion of the crown which had courts with authority to grant the writ. ${ }^{20}$ Although this necessarily limited the number of cases which came to London, there were a number of occasions in the late nineteenth and early twentieth centuries when habeas corpus cases involving what would now be called the rendition of political prisoners were heard by metropolitan judges, either when applications were made directly to the Queen's Bench or when cases came before the Privy Council on appeal from the colonies. These cases give a useful insight into the understanding and operation of the concept of the rule of law as it was being entrenched, via Dicey's work, in the conception English lawyers and law students had of their constitution. They also give insights into the relationship between law and politics. They often

${ }^{16}$ For instance, Ordinance No 3 of 1881 in the Gold Coast conferred power on the Governor to detain and deport 'certain political prisoners', in particular Asafu Ajay of Juabin and Elmina of King Tackie of Accra. PP 1883 [C. 3642] XLV.1, 112. In Sierra Leone, Ordinance No 8 of 1881 'legalised the detention of certain political prisoners and their deportation to Lagos': PP 1884 [C 4015] LIV.1, 176. In August 1881, Under Secretary of State Leonard Courtney admitted that three men had been kept in Freetown gaol as 'State prisoners, detained without any clear warrant of law', and that this was 'a scandal to our administration': Parl Debs 3rd ser, vol 45, col 726 (23 August 1881). In 1896, the Ashanti King Prempeh and 84 others were detained and exiled under the Kumasi Political Prisoners Ordinance 1896, on which see AWB Simpson, 'Round Up the Usual Suspects: the Legacy of British Colonialism and the European Convention on Human Rights' (1996) 41 Loyola L Rev 629, 636-37.

17 As Sir John Risley, a Colonial Office official, put it in 1923, 'Ordinances of this kind (containing provisions excluding Habeas Corpus proceedings) have been enacted from time to time for more than 40 years past, and I may say that since 1880 considerably over 60 have been passed by the West African colonies alone': T[he] N[ational] A[rchives] TS 27/172.

${ }^{18}$ In India, the Government had power under the Bengal State Prisoners Regulation (III of 1818) to detain and deport for 'reasons of state, embracing the due maintenance of the alliances formed by the British Government with foreign powers, the preservation of tranquillity in the territories entitled to its protection and the security of the British dominions from foreign hostility and from internal commotion'. This power was used in December 1908 to arrest and deport a number of prominent Bengali activists, who were not released until February 1910. It led to protests in parliament: see The Times (London) 10 May 1909, 6.

${ }_{19}$ Ex parte Anderson (1861) 3 Ellis and Ellis 487, 494.

${ }^{20}$ Habeas Corpus Act, 25 \& 26 Vic c 20. 
pitted the values of liberty and legality against those of security and executive prerogative, raising questions of how far legal rules could triumph over political judgment in cases involving state security. As shall be seen, depending on the political context, judges could either be champions of liberty or defenders of extensive executive powers, and a 'substantive' vision of the rule of law was sometimes defended more by parliamentarians than by judges. Nor were judges always given the full political picture, but were apt on occasion to be misled as to the true nature of the political crisis they were dealing with. They might therefore accord the executive great powers when even the executive itself knew that as a matter of political fact, they were not needed.

In what follows, the focus of attention will not be on the well-known habeas corpus cases that arose in wartime (such as Arthur Zadig's case) ${ }^{21}$ or under conditions of martial law (such as DF Marais's case). ${ }^{22}$ Rather, it will be on some less well-known cases that arose in peacetime and involved some form of rendition. We will explore how courts in London reacted to habeas corpus cases brought on behalf of prisoners who had been arrested in one place and moved to another. It is a question of some contemporary concern, given the recent decision of the Supreme Court in Rahmatullah $v$ The Secretary of State for Defence, ${ }^{23}$ where the court held that the writ could be issued on behalf of a prisoner who had been arrested by British troops in Baghdad and then handed over to American forces to be held in Afghanistan. In such cases, courts face two distinct questions: first, whether the detention is legal, and second (if it is not), whether the defendant has sufficient control of the body of the detainee for the writ of habeas corpus to be appropriate. As shall be seen, in the period under review, courts took an increasingly formalistic view of legality, which offered little protection to detainees, but at the same time took a much less formalistic approach to the question of control.

\section{Legality}

There were two approaches that could be taken in determining whether a prisoner's detention was illegal. On the one hand, courts could take a broad, substantive view of what the rule of law required, interpreting any particular legislative powers within a broad framework of common law rules protecting personal freedom and ancient statutes such as Magna Carta or the Habeas Corpus Act of $1640 .^{24}$ On the other hand, courts could take a narrow, formalistic approach, focusing on whether the particular legal instrument had been validly authorised by the sovereign power.

\section{Sprigg v Sigcau (1896)}

${ }^{21} R v$ Halliday, ex $p$ Zadig [1917] AC 260. On this case, see David Foxton, ' $R v$ Halliday ex parte Zadig in Retrospect' (2003) 119 LQR 455-94.

${ }^{22}$ Ex parte DF Marais [1902] AC 109. For this case, see D Dyzenhaus, 'The Puzzle of Martial Law' (2009) 59 U Toronto LJ 1, 31-34.

${ }^{23}$ Rahmatullah v Secretary of State for Defence [2012] UKSC 48, [2013] 1 AC 614.

${ }^{24} 16$ Car 1, c 10, s 8 . This statute ('An act for regulating of the privy council, and for taking away the court commonly called the star chamber') was commonly referred to as the Star Chamber Act. 
The first significant case to raise these matters was Sprigg $v$ Sigcau, heard by the Privy Council in 1896. The case concerned the detention without trial of the paramount chief of the Pondo. Lying between the colonies of the Cape of Good Hope and Natal, Pondoland had been ceded to the British Crown in 1894. Although a treaty with the Pondo had existed since 1844, the territory had never been annexed, in part because of the rival interests of the Cape Colony and Natal. However, after 1890, the area became increasingly unstable, because of a conflict between Sigcau and his former prime minister, Umhlangaso. In this context, in exchange for British support, Sigcau agreed first to accept a British resident in his territory, and then to a full cession. He was to remain nominally paramount chief, and was to receive a stipend, while his territory would be administered by the Cape government.

However, it proved harder to settle the tribal conflict after the cession than the Cape government had hoped, and Sigcau continued to intervene in local politics in a way which the colonial authorities found unhelpful. As part of the settlement brokered by the British, Umhlangaso was to be removed from the territory, and Sigcau was to be paid a fine of 200 cattle. However, Sigcau turned out not to have much of a 'disposition to heal old sores. ${ }^{25}$ He refused to accept a tender of 125 cattle and sought to humiliate Umhlangaso's followers. This was not the only complaint against him. Instead of explaining the system of hut registration (for tax purposes) to his people, Sigcau complained to them about his treatment, and insulted the white Registering Officers. Besides obstructing the work of registration, he also appeared to interfere with the British administration of justice. Sigcau clearly did not understand his place in the new dispensation. In June 1895, Sir Hercules Robinson, the governor of the Cape, accordingly issued a proclamation stating that Sigcau's presence in East Pondoland was a danger to public safety and good order and authorising his arrest and detention. On 18 June, he surrendered himself and was taken to Kokstad (in Griqualand East, into which East Pondoland had been merged). Four days later, the Governor-in-Council appointed a three-man commission ${ }^{26}$ to investigate Sigcau's conduct since the annexation of his territory. The commissioners reported that his conduct had 'been in many respects obstructive to the satisfactory magisterial administration of Pondoland' and that things would have been much better if his 'undoubtedly great personal influence over his people [had] been unreservedly and loyally used in support of the new method of government.' At the same time, they found that the attitude and conduct of the people as a whole had been praiseworthy, and that this was something for which 'the chief should receive some credit. ${ }^{, 27}$ Although there were no accusations of criminal or seditious conduct against Sigcau, he was informed on 13 July that he could not return to Pondoland. He was given the choice either to stay 'closely guarded' in unspecified territories nearby or be removed to the Cape Colony, where he would be allowed

\footnotetext{
25 'Report of the Commissioners appointed to inquire into the acts and behaviour of the Pondo Chief Sigcau since the annexation of East Pondoland' (in the Privy Council papers for Case No 12 of 1896: Sir John Gordon Sprigg v Sigcau: British Library: PP 1316) 8.

${ }^{26}$ They were the chief magistrate of Griqualand East, the assistant chief magistrate of Tembuland and Transkei, and the Cape Town chief of police. The inquiry (which sat in the first two weeks of July) was not a judicial one: evidence was not given on oath and judicial rules on admissibility of evidence were not observed.

27 'Report of the Commissioners' (n 25) 7.
} 
greater freedom. In response, Sigcau asked what crime he had committed, whether the proposed exile would be for life, and which territories he might be sent to. Having received no reply, on 29 July he petitioned the Cape Supreme Court for his release. ${ }^{28}$

At the hearing on the following day, counsel for the Cape government argued that the Governor had simply used his powers under the Cape's 1894 Pondoland Annexation Act, which stated that the territory 'shall be subject to such laws, statutes, and ordinances as have already been proclaimed by the High Commissioner, and such as, after annexation to the Colony, the Governor shall from time to time by proclamation declare to be in force in such Territories. ${ }^{29}$ In its view, the Cape parliament had effectively delegated legislative powers to the Governor, as far as the territories were concerned. Sicgau's lawyers countered that the Governor had no legal power to issue the proclamation under which he was detained. Indeed, they argued that even the Cape parliament itself had no power to pass a law to authorise his detention: for the powers of colonial governors were limited by their instructions, ${ }^{30}$ and one of the instructions was that the Governor should not assent to bills which were repugnant to the law of England or her treaty obligations. Since it was clearly repugnant to the law of England to pass a law which allowed for the imprisonment of an individual on the order of the governor, the legislation under which he had acted was void.

In a judgment which gave an eloquent 'substantive' defence of the rule of law, the Cape court ordered Sicgau's discharge. Sir Henry De Villiers CJ was clearly sympathetic to some of the broader arguments made for Sicgau, for he had no doubt that a bill which allowed someone to be imprisoned without any process of law would be repugnant to the law of England. ${ }^{31}$ However, he did not consider how far the Cape parliament's powers were limited by section 82 of the Constitutional Ordinance, in part because he was unsure of whether he had jurisdiction to consider the validity of a colonial act passed against the instructions given to a governor, and in part because he did not feel it necessary to do so. ${ }^{32}$ In his view, the central question in this case was not whether an act of the Cape legislature was valid, but whether the Governor had acted within his powers as a subordinate legislator. Stressing the importance of the separation of

\footnotetext{
${ }^{28}$ There was some concern in South Africa about the manner of his detention. As the Christian Express put it (1 August 1895, p 115) if Sigcau, now a subject of the Queen 'can be tried and banished by a court not being a regular court of justice, any other subject of Her Majesty may be similarly dealt with.'

${ }^{29}$ Pondoland Annexation Act, No 5 of 1894. The governor's powers in the territories were also governed by similar legislation relating to Tembuland (Act No 3 of 1885) and Griqualand East (Act No 38 of 1877).

${ }^{30}$ They cited Cameron v Kyte (1835) 3 Knapp 332 for this proposition.

${ }^{31}$ It 'would resemble a bill of attainder or a bill of pains and penalties, without any of the safeguards which English Parliamentary practice requires in the passing of such bills': [Record of Proceedings], Privy Council Case Papers [British Library: PP 1316], Case No. 12 of 1896: Sir John Gordon Sprigg v Sigcau, 20-21.

${ }^{32}$ At the same time he pointed out that 'The Parliament of this Colony has never yet passed, and it is not likely ever to pass, a bill for the condemnation of an individual without a fair trial.' Record (n 31) 22.
} 
powers, he noted that the statute had intended to confer on the Governor only legislative powers, not judicial ones. ${ }^{33}$ Nor had it given him the power 'of exercising arbitrary executive functions under the guise of legislative functions.' In the view of the chief justice, the Governor's proclamation could not be regarded as a law: for he explained - with assistance from the juristic works of Grotius, Bentham, and Austin - that the "term "laws" is wholly inapplicable to decrees directed against individuals'. In this case, the proclamation 'professes to proclaim a law but in reality it issues a decree which is partly executive and partly judicial but wholly arbitrary.' De Villiers spelled out the consequences of a finding for the crown:

If it was legal to sentence Sigcau to perpetual exile for his alleged 'obstructive' conduct, it would have been equally legal to sentence him to death, and the sentence could have been carried out before the meeting of Parliament. He is a native, but he claims to be and is a British subject, and there are many Englishmen and others resident in the territories who are not natives and who, if the Respondent's contention be correct, would be liable to be deprived of their lives and property as well as their liberty otherwise than by the law of the land. ${ }^{34}$

De Villiers was also sceptical about the crown's claims that there would be disorder in Pondoland if Sigcau were released, reiterating a comment he had made in an earlier case that a court's 'first and most sacred duty is to administer justice to those who seek it and not to preserve the peace of the country. ${ }^{35}$ In any event, he added that '[i]t must tend to enlist the natives on the side of the laws if they know that the Courts of law are as ready and willing to protect their legal rights as they are to punish them for offences against the law. ${ }^{36}$

The Cape authorities appealed to the Privy Council, and the case was argued in July 1896, with judgment being given the following February. The Judicial Committee rejected the appeal, but on a significantly narrower interpretation of the law. Lord Watson, giving the court's judgment, noted that the Governor's proclamation was cast 'in terms which are beyond the competency of any authority except an irresponsible sovereign, or a supreme and unfettered legislature, or some person or body to whom their functions have been lawfully delegated. ${ }^{37}$ Significantly, he added that if the Governor could have been shown to be in one of these positions, the court 'would be compelled, however unwillingly, to respect his proclamation'. However, the Judicial Committee

${ }^{33}$ This was evidently the case, he argued, since a comprehensive criminal code had already been proclaimed for the territory, and if the legislature had intended to give him power to punish offences not defined in code by his arbitrary judgment by proclamation, it would have expressed it in clear unambiguous terms: Record (n 31) 23.

${ }^{34}$ Record (n 31) 25.

${ }^{35}$ Record (n 31) 27, quoting from his judgment in In re Willem Kok and Nathaniel Balie (1879) in Eben J Buchanan, Cases in the Supreme Court of the Cape of Good Hope during the year 1879 (Cape Town: Juta 1880) 45, 66 [Juta Reports, 1879, 45].

${ }^{36}$ Record (n 31) 27. Cf 'The Liberty of the Subject' (1895) 12 Cape LJ 193-96, hailing the decision as a 'landmark for future generations' and questioning the government's decision to appeal and 'The Law of Personal Liberty in the Cape' (1896) 13 Cape LJ 252-55.

${ }^{37}$ Sprigg v Sigcau [1897] AC 238, 246. 
held that the Pondoland Annexation Act did not give the governor the power to make any new laws, but only allowed him to introduce into the territory general laws which already existed in other parts of the colony. The scheme of the legislation was 'to delay the enactment of many salutary laws elsewhere prevailing throughout the Colony until the native inhabitants of the newly annexed territories had so far advanced in civilization and in social progress as to make the gradual introduction of these laws advisable.' The Governor had simply acted ultra vires. ${ }^{38}$

\section{Ex parte Sekgoma (1909)}

Thirteen years later, the question of how to interpret legislation conferring general powers on a colonial governor came before metropolitan judges once again, in another case involving the detention of a southern African chief. The case arose from the detention in 1906 of Sekgoma Letsholathebe, the chief of the Tawana, from N'gamiland in the north-west of the Bechuanaland Protectorate. ${ }^{39}$ As with Sicgau's case, it was local tribal rivalries which caused all the trouble, for Sekgoma's right to be chief was disputed by the supporters of his nephew Mathiba. Although the British had initially supported Sekgoma's claims, after the turn of the century, they began to regard him as untrustworthy, and to favour his rival. ${ }^{40}$ Matters came to a head in December 1905 , at a point when Sekgoma had gone to Kimberley for medical treatment. In his absence, some members of his tribe sent for his nephew to come from Cape Town and assume the chieftainship. Hearing of this, Sekgoma set off to return to the tribe's capital, Tsau. Anticipating conflict, the High Commissioner, Lord Selborne, decided that they should both be kept away from their tribal homeland (the Batawana Reserve), pending an investigation into their claims. Sekgoma was met at Mafeking (in the Cape Colony) by two Bechuanaland policemen, and escorted to the Protectorate. ${ }^{41}$ On 20 April 1906, a warrant was issued in Serowe (in the Protectorate) to detain

${ }^{38}$ Sprigg v Sigcau (n 37) 247. The Cape Law Journal observed that (unlike the Cape Supreme Court, whose judgment it admired) the Privy Council had 'found it unnecessary to express any opinion on any of the constitutional questions raised in argument'; and rather chosen to place such a narrow construction on the Annexation Act which would 'necessitate immediate legislation to remedy, if chaos is not to prevail in Pondoland': (1897) 14 Cape LJ 85-93.

${ }^{39}$ On the Tawana, see A Sillery, The Bechanaland Protectorate (OUP 1952), ch 14. The protectorate was proclaimed in January 1885, though in September, the area of Bechuanaland south of the Molopo River was proclaimed to be part of British territory (British Bechuanaland), while the area to the north was to remain as the Bechuanaland Protectorate.

${ }^{40}$ See JM Chirenje, 'Chief Sekgoma Letholathibe II: Rebel or 20th Century Tswana Nationalist?' (1971) 3 Botswana Notes and Records 64-69, whose interpretation is debated further in A Sillery, 'Comments on Two Articles' (1976) 8 Botswana Notes and Records 292-95 and Chirenje, 'Military and Political Aspects of Map-making in Ngamiland : A Rejoinder to Anthony Sillery's Comment' (1977) 9 Botswana Notes and Records 157-59. See also AJGM Sanders, 'Sekgoma Letsholathebe's detention and the betrayal of a Protectorate' (1990) 23 Comparative and Int LJ South Africa 348-60.

${ }^{41}$ According to Selborne, he asked Chief Khama to hold both men in Serowe pending his arrival, whereupon he had discussions with them and issued the warrant (TNA T1 -11299, Letter from Selborne to C Riley, 22 March 1909; see also Selborne's speech to the African chiefs, reported in Mafeking Mail, 26 March 1910). According to Sekgoma's supporter Charles Riley, he was 
them both. Two months later, an inquiry held by Ralph Williams, the Resident Commissioner, in Tsau determined that Mathiba was the rightful chief. ${ }^{42}$

There were some doubts from the beginning about the legal basis for his detention. ${ }^{43}$ He appears to have been detained initially under the Expulsion of Filibusters Proclamation 30 June 1891, which had been aimed at removing disruptive Transvaal Boers from the Protectorate. Given doubts about the suitability of this provision, a replacement proclamation was issued by Selborne on 14 September 1906, which gave power to detain and remove from the Protectorate anyone reasonably suspected of being a danger to peace, order, and good government. ${ }^{44}$ This gave the authorities three months in which to detain him within the Protectorate. In the meantime, on 20 November, he applied to the High Court of Griqualand ${ }^{45}$ (which sat in Kimberley) to obtain his release. However, Lange J refused to hear the case, since he held that Sekgoma had neither been arrested nor detained in a place within the court's jurisdiction. ${ }^{46}$ With time running out for Sekgoma to be detained under the 14 September proclamation, on 5 December Selborne issued a second proclamation, which authorised his continued detention and declared that no writ calling in question the legality of his arrest, detention, or deportation should have any effect within the

'kidnapped in Mafeking' (in the Cape Colony) by the Bechuanaland Police in April 1906 on his way home: 'Proceedings, orders of the court and affidavits in connexion with an application for a writ of habeas corpus for the return of Chief Sekgome Letsholathebe', TNA CO 879/103/3, 247. The High Court of Griqualand, in which Sekgoma first sought a writ of habeas corpus, accepted his affidavit that he had been induced by the policemen to go with them to the Protectorate, but held that Sekgoma had not claimed to have been 'arrested' there. Sekgoma claimed in his affidavit that he had never been shown any warrant: Sekgome Letsholathebe v Panzera (22 November 1906) in Reports of Cases decided in the High Court of Griquland vol 10 (ed SB Kitchin, Juta 1911) 90, 92 [10 Griqualand High Court Reports 90].

${ }^{42}$ For his account, see Sir Ralph Williams, How I became a governor (John Murray 1913), ch 22. Sekgoma continued to claim that he was the rightful chief, and that all the difficulties had been caused by the intrigues of Chief Khama, Mathiba's cousin.

${ }^{43}$ When Sekgoma's advisers later asked for information about this detention, the Acting Resident Commissioner (Barry May) told Selborne, 'So far as I am aware there is no written information upon which the original warrant for the detention of Sekgoma at Gaberones was issued.' 16 March 1909: TNA T 1/11299.

${ }^{44}$ Note dated 6 September 1906 from EL Mathews (Legal Adviser): TNA DO 119/778. Mathews wrote, 'I can think of nothing better to safeguard persons against arbitrary arrest and removal than that they should be brought before a Court of Law. This will not apply to Sekgoma's case as he will be deemed to have been imprisoned by Court of Law'.

45 This was Griqualand West, the territory which lay in the northern part of the Cape Colony.

${ }^{46}$ On the first point, Lange noted that Sekgoma's affidavit 'does not allege that he was arrested in Mafeking, but goes on to say that he was detained at Palapye [in the Protectorate], and thence taken to Gaberones'; on the second, he held that there was nothing to show that the resident commissioner was within the jurisdiction of the court (even though his headquarters were in Mafeking, and the notice of motion had been served on him in Kimberley): Sekgome Letsolathebe v Panzera (n 41) 95. 
protectorate. $^{47}$ The British were keen to keep Sekgoma away from N'gamiland to prevent his reopening the dispute with Mathiba, which it was feared would end in bloodshed. Williams was particularly concerned for the fate of the fifteen white traders in the area, whose lives 'would most certainly be sacrificed.' The colonial authorities also thought that, with Sekgoma off the scene, the factions within the tribe would be reconciled.

For the next three years, Sekgoma remained confined in a yard surrounded by barbed wire in Gaberone. During this period, steps were taken by the government to obtain a solution under which he would be resettled with his cattle away from N'gamiland. ${ }^{48}$ Sekgoma's interests were represented by Charles Riley, who suggested in 1908 that he be allowed to settle near Mafeking. This proposal was rejected by the government, which instead offered to settle him in the Eastern Transvaal, which was far enough away to make the authorities confident that he would not attempt a return. Although initially inclined to agree, Sekgoma changed his mind in March $1909,{ }^{49}$ after Riley proposed going to London to put the 'case before the British public, and to get their support and sympathy. ${ }^{, 50}$ While both sides prepared for a battle in the British press and courts, negotiations continued over possible locations for Sekgoma's resettlement. ${ }^{51}$ Moreover, there were growing doubts among colonial officials about the policy behind the detention. ${ }^{52}$ It was in this context that Riley went (with the editor of a Mafeking newspaper and Sekgoma's African secretary) to London, first to present his arguments (without success) at the Colonial Office, and then in court. ${ }^{53}$

${ }^{47}$ For background, see TNA DO 119/778. The text of the proclamation is given in The King $v$ The Earl of Crewe, ex parte Sekgome [1910] 2 KB 576, 577-79. In the legal proceedings, his name was consistently misspelled as Sekgome.

${ }^{48}$ In 1908, hearings were conducted at Tsau under Proclamation 20 of 1908 to sort out rival claims to cattle. Letter from Barry May to Selborne 2 February 1909 in TNA T 1/11299. See also Rand Daily Mail (Johannesburg) 13 August 1908 ('Ngamiland Natives: No cause for alarm'). 49 'I will not go because I have committed no crime - I wish to have my case tried before the courts in England or else be killed.' Minutes of interview with Barry May, TNA T1/11299; quoted in Chirenje, 'Chief Sekgoma' (n 40) 67. See also Mafeking Mail (Mafeking) 14 December 1909 ('Sekgoma's Detention: Mr Peregrino's Interview. Will not settle in the Transvaal'); cf the appeal by his brother, in Rhodesia Herald (Salisbury) 2 October 1908, 11. ${ }^{50}$ Letter from Riley to Selborne, 5 March 1909, TNA T 1/11299.

${ }^{51}$ The colonial authorities first investigated whether he could be resettled near Mafeking, and then offered him resettlement on the north bank of the Molopo River.

${ }^{52}$ In March the Acting Resident Commissioner, Barry May, observed that the policy of removing Sekgoma from the chieftainship had not secured tranquillity in the tribe, which remained as divided as ever, while also expressing doubts about whether the anticipated bloodshed would materialise on his return. He stated that Bechuana tribes habitually split: had the dispute between these leaders occurred before British rule, 'there would probably have been some fighting of the half-hearted Bechuana kind' followed by the secession of one of the groups to form a new tribe, which would then live in peace with its neighbour. His view was that this was the natural result, which the current policy was blocking: Letter from May to Selborne, TNA T1/11299, 9 March 1909.

${ }^{53} \mathrm{He}$ initially intended to bring an action of false imprisonment against Selborne, but having 
The application for a habeas corpus was filed in October 1909. It was directed to the Colonial Secretary, Lord Crewe. In the view of Sekgoma's lawyers, Sicgau's case had established that a proclamation such as Selborne's was 'absolutely illegal'. ${ }^{4}$ However, as Lord Chief Justice Alverstone pointed out in granting the rule nisi, before the substantive matter of the power of the crown to detain by proclamation could be addressed, there were some objections to be met concerning the availability of the remedy. The first question was whether the English court was the proper court to issue this writ, and the second was whether the Colonial Secretary was the right defendant. The King's Bench Division found against the applicant on both scores. On the first issue, it held that he had gone to the wrong court. Instead of seeking a remedy either in the High Court of Griqualand or the King's Bench Division, he should have gone first to the courts in the Bechuanaland Protectorate, which (these judges felt) did have a jurisdiction to grant habeas corpus. They admitted that any judge in those courts would refuse the application, since the proclamation ousted their jurisdiction, but they held that Sekgoma could then take his appeal to the Privy Council, which could consider the validity of the proclamation. On the second issue, they held that the Colonial Secretary had neither custody of Sekgoma, nor control of his gaoler. Since his only power was to advise the crown, he was not the suitable recipient of the writ. ${ }^{55}$ This was, in fact, a rather artificial view to take: not only had Lord Crewe monitored all the negotiations with Sekgoma's representatives, but he was the man who took the final decisions. Indeed, when preparing for the case in September, the Colonial Office itself took the view that Crewe was the appropriate defendant. ${ }^{56}$ The judges in this court thereby avoided answering the principal question, though it was clear that they were uncomfortable with the ambit of the powers being claimed. ${ }^{57}$ In the Court of Appeal, the judges were less concerned with these remedial matters. They took the view that no courts existed in the Protectorate with power to issue the writ of habeas corpus. This meant that the 1862 Act did not apply, and the London court could hear the case. While they were less certain over whether the writ had properly been directed to Lord Crewe, ${ }^{58}$ they did feel it could be issued to an officer of the crown in London. ${ }^{59}$

failed to serve the writ on the departing High Commissioner, sought a writ of habeas corpus, on Sir Edward Carson's advice.

${ }^{54}$ This was Montague Lush's view, as expressed in the Court of Appeal. He went on (alluding to Sprigg v Sigcau), 'Lord Watson said it would be right if we had a despot who could issue edicts, but that such a proclamation was unknown to the English law': Proceedings (n 41) 72.

55 These judgments are in Proceedings (n 41) 63-69. Lush's argument was that Crewe could give directions under the Order in Council to Lord Selborne 'and until it is clear that no gaoler or anybody else would obey Lord Crewe, it is impossible to say that no return should be made': Proceedings (n 41) 55.

${ }^{56}$ According to an official, Crewe 'would not consider that he could defend an action on the ground that he was not personally responsible for the acts of Lord Selborne. Even if it were not done by his orders at the time, the detention is clearly being continued with his authority': Note from AHD 14 September 1909, TNA T $1 / 11299$.

${ }^{57}$ See eg Darling J's comment in Proceedings (n 41) 69.

${ }^{58}$ The judges endeavoured without success to persuade the crown to accept the inclusion of the actual gaoler in the writ, since this was a question of liberty: Proceedings (n 41) 121.

${ }^{59}$ Farwell LJ thought that where a man was 'under the control of an officer of the Crown who 
The main focus of the higher court's attention was on the substantive question of the validity of the proclamation. At issue were the powers of the High Commissioner. Since Bechuanaland had not been conquered, ceded, or settled, any power the crown exercised there derived from the 1890 Foreign Jurisdiction Act, ${ }^{60}$ which enacted that the crown's jurisdiction in such territories was of the same kind as it had in conquered lands. Orders in Council ${ }^{61}$ relating to such territories had the same effect as if they were part of the Act itself, and were not to be held 'void on the ground of repugnancy to the law of England'. Under an Order in Council issued on 9 May 1891, all the Queen's powers and jurisdiction regarding Bechuanaland had been conferred on the High Commissioner, who was empowered to do all things 'within the limits of this Order as are lawful' ${ }^{62}$ It also empowered him by Proclamation to provide for the administration of justice, the raising of revenue, and 'for the peace order and good government of all persons' in the Protectorate. The question for the court was whether the High Commissioner had the power to issue a Proclamation ordering the detention without trial of a named individual for an unspecified time.

Sekgoma's lawyers argued that he did not. Firstly, they said, even in conquered territories, the king's prerogative powers were limited by fundamental constitutional principles, which included the right to habeas corpus. In support of this argument, Montague Lush cited Lord Mansfield's dictum in Campbell $v$ Hall, that 'a country conquered by the British arms becomes a dominion of the King in the right of his Crown' and hence subject to parliament. While the king alone had the power to introduce new laws in such places, 'this legislation being subordinate [...] to his own authority in Parliament, he cannot make any new change contrary to fundamental principles', ${ }^{63}$ which included the right to habeas corpus. ${ }^{64}$ Secondly, these limitations on the king's powers were confirmed by section 12 of the 1890 Foreign Jurisdiction Act, which stated that no regulation could be made 'in any respect repugnant to the provisions of an Act of Parliament extending to the subjects of the Crown in that country'. In Lush's view, this meant that the crown

acts under the orders of the Colonial Office', the Colonial Secretary was the proper officer; while the others felt that a writ might properly be issued to Lord Selborne in his capacity as Lord Chancellor: Ex parte Sekgome (n 47) 592-93, 606, 618, 629.

${ }^{60} 53 \& 54$ Vic c 39 . This act consolidated a number of statutes dealing with foreign jurisdiction, dating from 1843.

${ }^{61}$ The 1890 Act did not itself make express provision for the issuing of Orders in Council, but as WE Hall noted, the first section by implication enabled the Queen in Council 'to make such Orders as may be necessary from time to time for the purpose of giving due effect to the jurisdiction': A Treatise on the Foreign Powers and Jurisdiction of the British Crown (Clarendon Press 1894) 10.

${ }^{62}$ Affidavit of Lord Crewe, which is in Proceedings (n 41) 248-49.

${ }^{63}$ Campbell v Hall (1774) 1 Cowper 204, 208-09. Cf Joseph Chitty, A Treatise on the Law of the Prerogatives of the Crown (Joseph Butterworth \& Son 1820) 29.

${ }^{64}$ Lush argued further that since the High Commissioner had set up a system of laws and procedures in Bechuanaland under earlier proclamations, he had set up a constitutional system from which he could not derogate by issuing a proclamation relating to one man alone: Proceedings (n 41) 92. 
was bound to observe the provisions of English legislation, such as Magna Carta and the 1640 Habeas Corpus Act, which declared that anyone imprisoned by the order of the crown might use habeas corpus. Lush also focused on the words in the Order in Council that gave the High Commissioner power to do such things 'as are lawful'. In his view, these words meant that the High Commissioner was only given the power of a sovereign bound by the British constitution, and not the powers of a despot. ${ }^{65}$ Moreover, having (by a Proclamation of 10 June 1891) set up a system of commissioners and magistrates to deal with criminal matters, it was not open to the crown to issue another proclamation detaining a single individual, under its powers to issue proclamations for the peace, order, and good government of the territories.

Against this, it was argued was that the crown had absolute powers of legislation in conquered lands. In such places, Sir William Robson AG argued, there could be 'no question of constitutional limitations such as we have in England or in a self-governing colony, where the King has parted with his prerogative'. ${ }^{66}$ It was also argued that Mansfield's notion that the common law of the motherland set limits to what could be done in colonial legislation had been superseded by later legislation, including section 12 of the 1890 Act itself, and the 1865 Colonial Laws Validity Act on which it was based. ${ }^{67}$ In addition to this argument, the crown contended that Sekgoma's detention was an act of state which was not to be questioned in a court. Habeas corpus was not, in the crown's view, a writ which could be used by a foreigner held outside the crown's territorial dominions. His lawyers countered that Sekgoma could not be regarded as a foreigner, since in Bechuanaland 'every single legislative and judicial and domestic power has been taken from the native sovereign and absorbed by the Crown'. ${ }^{6}$

Sekgoma lost his appeal. The judges agreed that the power of the crown to legislate in Bechuanaland was not limited by any fundamental law. The question of whether the powers of colonial legislatures were limited by such principles had already been discussed in cases on the Colonial Laws Validity Act of 1865, in which it had been held that laws passed by local legislatures were not to be regarded as invalid for being repugnant to English law, unless the English legislation was directly applicable to the colony. ${ }^{69}$ Moreover, the analogous provision in

${ }^{65}$ Proceedings (n 41) 91-92.

66 ibid 42.

67 ibid 159.

68 ibid 30. There was much discussion at the hearings over whether the foreign Jurisdiction Act only gave the crown extra-territorial jurisdiction over British subjects (as Hall thought, in $A$ Treatise on the Foreign Powers (n 60) 221-22) or whether it also applied to 'natives of such foreign countries'. The court took the latter view: Exp Sekgoma (n 47) 596.

${ }^{69}$ In Phillips v Eyre (1869) LR 4 QB 225, (1870) LR 6 QB 1, where the court had to consider the validity of an indemnity act passed by the Jamaica assembly to protect Governor Eyre, Willes $\mathbf{J}$ rejected arguments that a legislature created by the crown only had powers limited by the Mansfield's 'fundamental law'. He ruled that 'a confirmed act of the local legislature lawfully constituted, whether in a settled or conquered colony, has, as to matters within its competence and the limits of its jurisdiction, the operation and force of sovereign legislation, though subject to be controlled by the imperial parliament': LR 6 QB 1, 20. Cf Riel $v$ The Queen (1885) 10 App Cas 675, 678-79. 
section 12 of the Foreign Jurisdiction Act had already been considered by the Judicial Committee of the Privy Council in 1899, in The Queen $v$ Staples. In this case, a settler who had been convicted of theft in a Matabeleland court made up of a judge and two assessors - but no jury claimed that his rights under Magna Carta had been violated. The Privy Council rejected his claim, Lord Halsbury pointing out that the Foreign Jurisdiction Act gave the crown 'absolute power to say what law should be applied, as if it was by absolute conquest'. ${ }^{70}$ In the court's view, '[i]t would be a most unreasonable limit on the Crown's power of introducing laws fitting to the circumstances of its subjects in a foreign country if it were made impossible to modify any Act of Parliament which prior to the Order in Council might be invoked as applicable to a British subject.' 71

For Vaughan Williams LJ, the consequence of this interpretation of section 12 was that the crown retained its inherent unlimited power of legislating in conquered lands. ${ }^{72}$ By contrast, Farwell LJ inclined to the view that the crown itself might be limited by a fundamental law, but that parliament was not: and that the powers exercised by the crown here derived solely from the 1890 statute. $^{73}$ That statute stated that Orders in Council issued under it were to have the same effect as if they were in the act, while the 1891 Bechuanaland Order in Council stated that proclamations were to have the same effect as if they were contained in the order: consequently, the proclamation had the effect of legislation. ${ }^{74}$ The judges also addressed the question whether a proclamation drawn up for one man - in effect a privilegium - fell within the High Commissioner's powers to legislate for the 'peace, order and good government' of the territory. Although Vaughan Williams was concerned by the fact that the December proclamation under which Sekgoma alone was detained ignored the earlier September proclamation which set out a procedure for dealing with those to be kept out of Bechuanaland, he was not prepared to say that this rendered the later ad hominem proclamation void. ${ }^{75}$ Finally, two of the judges - Kennedy and Vaughan Williams LJJ - also seemed inclined to accept the argument that the detention of Sekgoma had been an act of state, for which a writ of habeas corpus could not be brought. Vaughan Williams LJ accepted that Bechuanaland had never become a territory of the crown, and that Sekgoma, who had been described as a British subject in the crown's documents, was not a subject in the same sense as 'an Englishman resorting temporarily to the Protectorate'. In

\footnotetext{
${ }^{70}$ This was subject to the qualification in s 12 that 'if Parliament in respect of that same country has passed an enactment on the subject, Her Majesty is not given power to alter that': The Queen $v$ Staples, Report of Proceedings before the Judicial Committee of the Privy Council, 27 January 1899: Memorandum of Reasons for the decision of the committee, TNA CO 879/103/2, p 12.

${ }^{71}$ The Queen v Staples (1899) TNA CO 879/103/2, p 3; quoted by Farwell LJ, Ex p Sekgome (n 47) 615 .

72 In his view, the 'fundamental law' limitation invoked by Mansfield did not apply in this case, as the crown had reserved the right to disallow any proclamation, and so had never yet created a permanent system of laws in the protectorate: Ex parte Sekgome (n 47) 599. Kennedy LJ thought that the crown had power to legislate in Bechuanaland independently of the 1890 Act: ibid 626.

${ }^{73}$ Ex parte Sekgome (n 47) 612.

${ }^{74}$ Kennedy LJ held that the 1890 Act was intended to delegate very extensive discretionary powers: Ex parte Sekgome (n 47) 627.

${ }^{75}$ Ex parte Sekgome (n 47) 604; cf similarly Kennedy LJ's views at 628.
} 
his view, although the Englishman might be able to obtain a writ of habeas corpus, the African could not. ${ }^{76}$

Sekgoma's attempt to appeal to the fundamental principles of the common law foundered on the rock of parliamentary sovereignty, which was taken to have removed these ancient rights. The highly formalistic approach taken by the judges when considering the nature of the High Commissioner's powers rested on a policy developed in the mid-century regarding self-governing colonies. By that era, it had become apparent that self-governing colonies could not be constrained to pass no laws repugnant to England's. ${ }^{77}$ Policymakers in London were also aware that colonial legislatures should have the power to suspend habeas corpus in times of need: in such cases, the constitutional guarantee against executive abuse would lie in the representative assembly. But when it came to the exercise of delegated powers of legislation in a colony or protectorate without a legislative assembly, it was less apparent that the governors should be held to have unfettered legislative powers, at least in the absence of more specific wording indicating that the legislature had intended to confer powers to interfere with liberty. Nor was it entirely clear that the case law from the self-governing colonies had definitively settled the question of whether or not Magna Carta and the Habeas Corpus Act 'extended' to the colonies by 'necessary intendment'. ${ }^{78}$ In many ways, the key precedent for the Court of Appeal in Sekgoma's case was consequently the unreported case of Staples, where the Privy Council held that the crown was not bound by Magna Carta in issuing Orders in Council under the Foreign Jurisdiction Act. Farwell LJ certainly seemed to think that this case had clarified the meaning of 'necessary intendment': 'You see that Magna Charta is almost as much one of our great Charters of liberty as habeas corpus if not more,' he observed during argument, 'and they have held that because there were no words to answer the phraseology of the Act extending to Her Majesty's subjects in that country but only perfectly general words the Magna Charta did not apply'. However, (as Lush retorted) that case did not involve the kind of violation of natural

76 'It may be that an Englishman resorting to the Bechuanaland Protectorate carries the habeas with him, but Sekgome certainly does not': Ex parte Sekgome (n 47) 607. Kennedy LJ observed that if Gaberones were 'within the foreign dominions of the Crown', the court would have jurisdiction to issue habeas corpus to Sekgoma, even if he were not a British subject, but held that Bechuanaland was not one of the crown's dominions, and that the order to detain him was an act of state.

77 The Colonial Laws Validity Act was passed in response to the efforts of a South Australian judge, Benjamin Boothby, to challenge the legitimacy of local legislation on the grounds of inconsistency with English law: see WR Cornish and others, The Oxford History of the Laws of England vol 10 (OUP 2010) 242 and B Kercher, An Unruly Child: A History of Law in Australia (Allen \& Unwin 1995) 97-102.

78 The principal cases were Phillips $v$ Eyre (1870) LR 6 QB 1 and Riel v The Queen (1885) 10 App Cas 675. In the former case, Willes J addressed the argument that a colonial statute might be void for being contrary to 'some principle of natural justice', but held that the (ex post facto) Jamaica indemnity statute could not be regarded as 'naturally or unnecessarily unjust' (LR 6 QB 20, 27). These comments were taken by Farwell LJ to have 'disposed of' the arguments of natural justice, which Lush sought to advance in Sekgoma's case: Proceedings (n 41) 218, Ex parte Sekgome (n 47) 614. 
justice found in Sekgoma's case, nor had the key constitutional points been fully argued. ${ }^{79}$

The judges' very formalistic interpretation of the law in Sekgoma's case - one which contrasts with the approach taken in Cox v Hakes - is perhaps to be explained by their confidence in the probity of the colonial officials, and in their racially-informed understanding of the colonial context, which made them think such draconian measures were necessary. While the judges showed themselves to be uncomfortable with the idea that these powers might be used against white men, there was a continuing presumption that the same rules might not apply to people of colour. "The idea that there may be an established system of law to which a man owes obedience, and that at any moment he may be deprived of the protection of that law, is an idea not easily accepted by English lawyers,' Vaughan Williams LJ concluded, 'It is made less difficult if one remembers that the Protectorate is over a country in which a few dominant civilized men have to control a great multitude of the semi-barbarous. ${ }^{, 81}$ Lord Justice Farwell stated that 'in countries inhabited by native tribes who largely outnumber the white population', the 'bulwarks of liberty' which protected the English people 'might, if applied there, well prove the death warrant of the whites' ${ }^{82}$ Lord Justice Kennedy similarly took the view that a wide interpretation of the power of the High Commissioner to make regulations for the peace order and good government was 'especially just and necessary where, as is the case here, the trustee has to govern a large unsettled territory, peopled by lawless and warlike savages, who outnumber the European inhabitants by more than one hundred to one. ${ }^{83}$

These preconceptions had no basis in the colonial reality. By 1909, local colonial officials themselves conceded that Sekgoma's detention had done nothing to resolve the underlying tribal conflict, which was bound to result in a relatively peaceful secession of one part of the tribe, as was the norm in Tswana tribal politics. Nor was there much plausibility in the fear that the lives of the 15 white traders in the area were at any kind of risk. Sekgoma's detention was a matter of continuing policy, not urgent necessity. It is also not insignificant that the negotiations about his release continued throughout the time that the case was before the courts. In the month before the Court of Appeal's decision, lawyers for both sides in Mafeking proposed a settlement under

\footnotetext{
${ }^{79}$ Proceedings (n 41) 217-18. The argument that Staples carried with him the right to an English jury under Magna Carta was problematic in a number of ways. As Lord Chancellor Halsbury pointed out, a strict reading of Magna Carta might prevent the crown from creating any new courts at all. Moreover, there were practical difficulties in providing for jury trials in Matabeleland, given the paucity of white settlers. Finally, Staples had migrated from the Cape, where jury trials were a creature of statute. In the event, much of the discussion before the Judicial Committee did not turn on s 12 of the 1890 Act but on whether Matabeleland could be considered a 'foreign' jurisdiction subject to the Act: TNA CO 879/103/2.

${ }^{80}$ The problem of figuring out how far English liberties extended in the empire was encapsulated in the following exchange from the first hearing (Proceedings (n 41) 28):

Mr. MontAgue LuSH: Magna Charta says, - I forget the exact terms of it -

Mr. JUSTICE DARLING: 'Nullus liber homo'; it does not say 'Nullus niger homo.'

${ }^{81}$ Ex parte Sekgome (n 47) 609-10.

82 ibid 615.

83 ibid 627.
} 
which he would be released with compensation. Although the settlement was delayed when the High Commissioner took exception to the amount of compensation offered to Sekgoma, ${ }^{84}$ the government eventually agreed to place him and his followers on land on the north bank of the Molopo, and to pay his legal costs. Sekgoma - 'the black Dreyfus' - was finally released in March $1911 .^{85}$

\section{Ex parte Saad Zaghlul Pasha (1923)}

Sekgoma's case confirmed Lord Watson's point in Sigcau that parliament could authorise detention without trial, even through general delegated legislative powers. In 1923, the Privy Council was asked to consider the position where the crown acted only under its prerogative power in removing and detaining a political opponent. The detainee in this case was a much better known figure than the two southern African chiefs: it was Saad Zaghlul Pasha, the Egyptian nationalist leader, and sometime Minister of Justice in Egypt. Born around 1857, Zaghlul had been a moderate nationalist politician in the first decade of the century, largely in sympathy with British rule, but had adopted a more extremist position after 1913. In the wake of the Anglo-French declaration of November 1918 promising self-determination for the Arabs freed from Ottoman rule, he helped form a political party, the al-Wafd al-Misri, which campaigned for complete independence. Zaghlul's effectiveness as an agitator led to his being deported to Malta in March 1919 (with three others), though the unrest this generated forced the British authorities to release him. Over the next two years, Zaghlul put himself at the centre of the Wafd, as the sole authentic interpreter of the people's wishes, and derided any other attempts to negotiate with the British, who for their part regarded him as an unstable and dangerous adversary, and an obstacle to their securing a settlement in Egypt under which they would retain considerable powers. ${ }^{86}$ Matters came to a head towards the end of 1921. On 21 December, after Zaghlul had announced a mass meeting for the following week, the High Commissioner, Sir Edmund Allenby, banned the meeting and prohibited him from participating in politics. When Zaghlul refused to comply, he and four others were arrested. Although Allenby claimed that these measures were only taken to curb the recent 'harmful agitation', ${ }^{87}$ it was evident that the prime reason for his arrest was that Zaghlul was a severe political inconvenience. Once it was clear that he would refuse to desist from political activity, the government felt it had no option

\footnotetext{
${ }^{84}$ See the documents transmitted by Selborne to Crewe on 4 April 1910 in TNA T 1/11299.

${ }^{85}$ The Times (London) 6 March 1911, 5a. He was given this epithet by Tsala ea Becoana (Friend of the Bechuana) (Kimberley) 30 July 1910. As it explained on 18 March 1911, 'if the colour of his skin was white there would be donnybrook over this piece of administrative tyranny; in fact, he could not have remained in gaol for ten days'. He died (of kidney disease) at Kavimba in January 1914: TNA CO 879/115/5, p 5. After his death, the Resident Commissioner of Bechuanaland recommended the return of all his people to the Batawana Reserve, and to seek to effect a reconciliation with the followers of Mathibe.

${ }^{86}$ On Zaghlul Pasha, see Afaf Lutfi Sayyid-Marsot, Egypt's Liberal Experiment, 1922-36 (University of California Press 1977) ch 2. See also 'Outline of Saad Pasha Zaghlul's career as a nationalist leader, more particularly since the Proclamation of the British Protectorate over Egypt on December 18, 1914', TNA TS 27/172.

${ }^{87}$ Parliamentary Papers 1922 [Cmd. 1592] XXIII.25, p 21.
} 
but to deport him. ${ }^{8}$ His removal provided the British with the opportunity to obtain the settlement they wanted, and on 28 February, they announced the termination of the Protectorate. $^{89}$

After being held in Suez and Aden, Zaghlul was moved on 1 March 1922 to the Seychelles, and detained under an Ordinance passed three weeks earlier. ${ }^{90}$ However, over the summer, concerns were raised over the effect of his detention in this location on his fragile health. ${ }^{91}$ Given these concerns, a decision was taken to move him to Gibraltar. He would be detained there under a Political Prisoners Detention Ordinance, ${ }^{92}$ which was passed two weeks after he sailed from the Seychelles on 16 August. The wording of the principal provision of this order - relating to the power to detain - was almost identical to the Seychelles Ordinance, but it included a provision (section 4) not found in the latter: 'No writ of Habeas Corpus or other process calling into question the legality of or other matter connected with the arrest, deportation or detention of the said prisoner or prisoners shall have any force or effect in the Colony. ${ }^{93}$

Zaghlul arrived in Gibraltar on 3 September, one day before the publication of the order. Soon afterwards, he made an application to the Supreme Court of Gibraltar for a writ of habeas corpus. His lawyers argued that section 4 of the Ordinance was 'unconstitutional', since the Governor did not have any power under the Letters Patent and Royal Instructions which defined his commission to deprive any detainee of the right to apply for habeas corpus. ${ }^{94}$ The application was dismissed by Daniel T Tudor CJ. Mistaking the facts, he held that Zaghlul had been convicted by a court martial in Egypt prior to his deportation, and so had been detained by legal process. He also held that the governor had not exceeded his powers. Rejecting the argument that the Governor had gone beyond the limits set by the Royal Instructions, Tudor CJ said it was impossible to conceive 'how this enactment could have been framed', or Zaghlul detained as a political prisoner, without instructions conveyed by one of the Principal Secretaries of State. It was obvious that Zaghlul's 'detention is authorised by an act of state', which the court could not look into. ${ }^{95}$ As this judge well understood, the relevant strings in this case were being pulled in

${ }^{88}$ The Times (London) 16 March 1922.

${ }^{89}$ For the announcement, see Parl Debs, 5th ser, vol 49, col 236.

90 The Political Prisoners Detention Order 1922 (Seychelles Ordinance No. 1 of 1922, passed on 10 February) empowered the Governor of the Islands to detain any political prisoner deported from Egypt. A copy is in TNA TS 27/172.

91 TNA TS 27/172; letter from Saphia Zagloul dated 8 July 1922. Zaghlul suffered from diabetes, chronic bronchitis, and had damaged lungs as a result of an earlier attack of pneumonia. See also Parl Debs, 5th ser, vol 153, col 1789 (8 May 1922), vol 156, col 1054 (11 July 1922).

${ }^{92}$ Gibraltar Order no. 9 of 1922. A copy is to be found in TNA TS 27/172.

${ }^{93}$ Although not found in the Seychelles Ordinance, this was a standard form devised by the Colonial Office and used in other colonial instruments: see eg the Political Prisoners Ordinance 1882 of the Gold Coast Colony, in TNA TS 27/172.

${ }^{94}$ In support of this argument, GMT Hidyard cited Musgrave v Pulido (1879) 5 App Cas 102 in which the Privy Council had held that the Governor of a colony only had such powers as were conferred on him by his commission.

${ }^{95}$ Re Zaghlul Pasha (1922) in (1813-1977) Gib LR 58. 
London, not in Gibraltar.

In contrast to Sekgoma's case, Zaghlul's incarceration continued to attract a great deal of political attention, both in London and Cairo. ${ }^{96}$ It was in the context of continuing public debate over his detention that a petition was lodged in the Privy Council for special leave to appeal against the decision of the Gibraltarian court. The case was argued twice, in January and March 1923. At the same time that the case was proceeding, the government held numerous discussions with Egyptian nationalists connected with Zaghlul to find a way to release him, while avoiding his return to Egypt. ${ }^{97}$ It was a process in which the Governor of Gibraltar - whose Ordinance was ostensibly passed for the peace, order, and good governance of his colony - played no part. The case raised the question whether the crown could 'detain as a prisoner in Gibraltar an Egyptian subject being a subject of a nation at peace with Your Majesty who was for political reasons arrested in, and deported from Egypt without any charge being made against him and without trial, by order of Your Majesty's High Commissioner in Egypt claiming to act under "Martial Law". ${ }^{98}$ Zaghlul's lawyer, WH Upjohn, rejected Tudor CJ's idea that this was an act of state. Significantly, he conceded that the court would have no power to question Zaghlul's detention in Egypt, since the court had no jurisdiction over aliens detained outside the empire. ${ }^{99}$ However, he argued that once Zaghlul was on imperial soil, he was a 'friendly alien' entitled to the rights and

\footnotetext{
${ }^{96}$ Eighty-four Liberal and Labour MPs addressed a letter to the Prime Minister on 9 December calling for his release. The letter was co-ordinated by JM Kenworthy. A copy can be found in TNA FO 141/809. For views among British residents in Egypt that Zaghlul's continuing detention was exacerbating the situation, see The Times (London) 30 December 1922. In this atmosphere, Allenby sought a friendly parliamentary question, to allow the government to make it clear that people were not being detained simply for their political views but for provoking violence: Telegram from Cairo High Commission 12 December 1922, TNA FO 141/809. The question was duly asked and answered with Allenby's formulation: Parl Debs, 5th ser, vol 159, col 3353.

${ }^{97}$ As early as the second week of December, the Egyptian Prime Minister had asked Allenby whether it would not be possible to allow him to go to Vichy to recover, on condition that he did not return to Egypt: letter from EM Dowson to Scott, 11 December 1922, TNA FO 141/809. A medical report on the day of the second hearing stated that he should travel to a European watering place for the sake of his health, and Zaghlul petitioned the French government to be allowed to go there. Though he had opposed Zaghlul's release in December, Allenby now formed the view that he could be released, without his giving any guarantees: Telegrams of 22 March and 24 March 1923, TNA FO 141/794/9.

${ }^{98}$ Petition of Zaghlul Pasha, TNA TS 27/172. The petition pointed out Tudor CJ's error in assuming that Zaghlul had been convicted, and also claimed that the English Habeas Corpus Acts of 1879 applied in Gibraltar.

${ }^{99}$ Both Upjohn and the Privy Council judges were uncertain as to the exact status of Egypt in the period in question. The Attorney General clarified this (noting that it had been a Protectorate after 1914), but Upjohn continued to be of the view that the writ of habeas corpus would not run outside the empire itself: In the Matter of Zaghlul Pasha: Petition for Special Leave to Appeal, TNA TS 27/172.
} 
liberties of a subject. ${ }^{100}$ Not much time was devoted to arguing this point, as the judges were convinced that the case could not be settled by the 'act of state' arguments used by Tudor CJ. ${ }^{101}$

Upjohn's second argument was to impugn the Ordinance. Accepting that the Governor had implemented a command from London, he drew on Mansfield's dictum in Campbell v Hall that the king himself could not authorise an ordinance which went against fundamental laws. However, he soon found the judges less receptive to this argument. When Upjohn argued that it was the 'law in every civilised country of the world that a man is not to be condemned without being heard,' Lord Sumner observed, 'There are many kinds of civilisation, ours is not the best'. ${ }^{102}$ The judges were not prepared simply to accept Upjohn's universal principles: they wanted more specific information to see how the particular rights Upjohn claimed for Zaghlul had become law in Gibraltar. However, neither side was at this stage prepared for an argument in the Privy Council over what the law of Gibraltar actually was. Given the lack of information, the hearing was adjourned for more research to be done.

The research showed that after Gibraltar had been ceded to Britain by the Treaty of Utrecht in 1716, a number of charters had been issued setting up courts administering English law. ${ }^{103}$ They had been followed by orders in council in 1867 and 1884, which stated that the law of England was to apply, except insofar as otherwise provided for by any order in council or local ordinance past or future. With this information in hand, Colonial Office lawyers prepared three main points to answer any case against them. First, they argued that the writ of habeas corpus was not available to Zaghlul. Applying the test of the Colonial Laws Validity Act, they took the view that the Habeas Corpus Act of 1679 could not apply to Gibraltar. ${ }^{104}$ As to the common law writ, it could only derive its force in Gibraltar from its express importation in the 1884 Order in Council, which reserved the power to change any Gibraltarian law (including that relating to habeas corpus) by local Ordinance. Second, even if the Governor had gone beyond the Royal Instructions in passing this ordinance, he would only be answerable to the Secretary of State and not to the courts. ${ }^{105}$ Third, both Sekgoma's case and the wartime decision in $R v$ Halliday ${ }^{106}$

${ }^{100}$ He rested the argument on Johnstone v Pedlar [1921] 2 AC 262. This case held that the crown could not claim that the seizure of the property of a friendly alien [alien ami] resident in the United Kingdom was an act of state.

${ }^{101}$ Gibraltar, unlike Bechuanaland, was not a Protectorate, and not a 'foreign' territory. It was long established that friendly aliens could seek the writ of habeas corpus: Case of Hottentot Venus (1810) 13 East 195.

${ }^{102}$ In the Matter of Zaghlul Pasha: Petition for Special Leave to Appeal, TNA TS 27/172, p 38. Haldane also seemed to doubt the claimed universalism of these rights: for (having clearly read his Dicey), he pointed out that in Belgium, all freedoms depended only on constitutional guarantees.

${ }^{103}$ There had been such charters in $1720,1739,1752,1817$, and 1830.

${ }^{104}$ In taking this view, they invoked Ex p Sekgoma: letter from Sir John Risley to HM Greenwood, 16 January 1923, TNA TS 27/172. They also rejected the idea that the case of Ex parte Anderson (n 19) had the effect of so extending it: letter from Sir John Risley to Sir John Mellor 23 February 1923.

${ }^{105}$ Risley to Greenwood, 12 January 1923, TNA TS 27/172. 
showed that it might be necessary for the sake of peace, order, and good government to make a privilegium ordering detention without trial. The crown's argument was simple. As a conquered territory, in which the crown had reserved the power to alter any of the charters it had granted, the crown retained the full power to legislate. The only constitutional limit on the king's power, according to Sir Douglas Hogg AG, was that he could not wholly oust the jurisdiction of parliament over a territory. There was no inherent right to a writ of habeas corpus in such colonies: it was only available insofar as local legislation provided for it. In response, the position of Zaghlul's lawyers was that the series of charters and orders that had been issued in Gibraltar since its conquest meant that the fundamental rights of Englishmen had taken root on the rock, including the writ of habeas corpus, and could not simply be revoked by an order in council dating from 1884.

When the case returned to court on 9 March, it was not to determine whether Zaghlul should be freed, but only whether there was a serious enough constitutional issue raised for leave to appeal to be granted, so that the substantive matter would be debated at a full hearing. During the discussion, Viscount Haldane appeared inclined to accept Upjohn's arguments. Citing Coke, Mansfield, Dicey, and Anson, he suggested that prerogative powers were bound by the common law, and had to be exercised in a way consistent with Magna Carta and the Bill of Rights. He also suggested that Ex parte Anderson ${ }^{107}$ showed that the writ of habeas corpus did run throughout the empire, and that it could only be removed by an Act of the Imperial Parliament. ${ }^{108}$ 'I am sorry,' he said, 'but I do think a very considerable question arises whether the Prerogative of the Crown as regards places altogether outside these Islands without a Constitution can be exercised otherwise than in accordance with the law. ${ }^{109}$ However, the Attorney General, Sir Douglas Hogg, was keen to impress on the judges the importance of not allowing the case to proceed to a full argument: 'having regard to what is going on in Egypt', he said, 'it would be 'a very very serious matter from the political standpoint' for the case to go forward. ${ }^{110}$ Hogg's arguments convinced the majority of the judges. Lord Atkinson, who was on the panel, had already expressed the view (in $R v$ Halliday) that statutes protecting liberty were not to be interpreted in a different way from any other statutes - a comment which Hogg did not fail to bring to the attention of the judges. Lord Dunedin, who pointed out that Magna Carta did not apply in Scotland, perceived that the crown was simply using its legislative powers to do in Gibraltar what the imperial parliament had done in England during the war. ${ }^{111}$ Lord Wrenbury simply said, 'I cannot follow why, in fact, if the King is the legislative authority, he could not legislate'. ${ }^{112}$ Nor did Lord Sumner feel that Gibraltarian law was subject to control by any

\footnotetext{
${ }^{106} R$ v Halliday (n 21).

107 Ex parte Anderson (n 19).

${ }^{108}$ During the discussions, Haldane had seemed to suggest a possible alternative route for Zaghlul to pursue: if the court in Gibraltar was unable to issue a writ of habeas corpus (because of the Ordinance), then he could try to obtain one from the King's Bench in London.

${ }^{109}$ In the Matter of Zaghlul Pasha, TNA TS 27/172, p 17.

110 ibid 10, 26.

111 ibid 10-11.

112 ibid 30.
} 
fundamental principles. ${ }^{113}$

Given his views, it was perhaps ironic that it was Haldane who was chosen to pronounce the decision that leave would not be granted. ${ }^{114}$ The majority on the judicial committee interpreted the crown's prerogative power to legislate in a highly formalistic way, unrestrained by a wider substantive notion of the rule of law. According to their understanding, Dicey's nuanced constitutional system - which brought together the rights derived from the common law tradition with a parliament acting as the guardian of that tradition - was irrelevant in the colonial context: the crown's powers in the conquered colonies were separate and distinct from the common law system at home. Until such point as parliament directly imposed its will on the conquered colonies, the crown had an unlimited power to legislate as it saw fit. This legal fragmentation, distinguishing between the crown's powers in different locations, placed obstacles in the way of those who had been moved from one part of the British dominions to another, and who sought to vindicate the substantive notion of the rule of law that no one could be imprisoned save by due process of law. It meant that ministers in London would be at liberty to move political detainees around the empire in time of peace, without needing to account for their actions either in parliament or in the courts.

It was all too evident to them that this legal compartmentalisation of the empire did not reflect political reality. In Zaghlul's case, every decision concerning his detention was made between London and Cairo: the Governor of Gibraltar did not even decide how many guards were to be stationed in front of the house where Zaghlul was detained. ${ }^{115}$ It is therefore ironic that one constitutional commentator argued that '[t]he security for the prevention of injustice', in cases such as Zaghlul's, lay in the 'royal power of disallowance' exercised by the Colonial Office, for he appeared to be unaware of the fact that in this case the Colonial Office was itself calling the shots. ${ }^{116}$ For men like Zaghlul, the broader substantive notion of the rule of law had to be vindicated by the political process, rather than the legal one. In contrast to Sekgoma's case, Zaghlul's incarceration continued to attract a great deal of political attention, both in England and Egypt. It was of particular interest to Labour MPs, some of whom had themselves been detained during the war, who ensured that the government remained under intense political pressure over what to do with this high profile detainee. Furthermore, at the same time that Hogg

113 'The Island of Ascension,' he pointed out, 'was until quite recently a Frigate on the list of the Navy, and was governed accordingly': ibid 32.

${ }^{114}$ No reasons were given. The decision was reported in The Times (London) 10 March 1923, 4 and in (1923) 67 Solicitor's J 382.

115 These decisions were taken in Cairo: see the letter from the High Commission in Cairo to the Governor, 4 March 1923, TNA FO 141/794/9.

${ }^{116}$ A Berriedale Keith, Notes on Imperial Constitutional Law (1923) 5 (3rd ser) J Comparative Legislation and Int L 277-78. He noted that the case showed 'in a striking manner' how large the legislative powers of the crown were in colonies such as Gibraltar. However, he did not think it created any new precedent, but merely recognised that the crown retained full powers to legislate in such colonies, and that it was not for the courts to consider whether any act was for peace, order and good government, since that would entail the judicature invading the province of the legislature. 
was warning the judges about the very dire consequences of even allowing a public airing of the constitutional issues, a much more flexible political game was being played, as plans were laid for his release. As in Sekgoma's case, the judges' decision was influenced by their understanding of the political necessities of Zaghlul's detention: but this understanding was built on limited and misleading information. Less than a month after the hearing, Zaghlul left Gibraltar for France. With the lifting of martial law in Egypt, he was told that he could return to his homeland, and he did return on 17 September. Four months later, he was Prime Minister of Egypt, and when in September 1924, he came to visit his British counterpart, Ramsay MacDonald, in Downing Street, a feature in the Illustrated London News could proclaim that 'Egypt as she is to-day is the work of Lord Cromer, the Administrator; Lord Kitchener, the soldier; and Saad Pasha, the Nationalist'. 117

\section{Ex parte O'Brien (1923)}

It was not just Zaghlul's detention which was making political waves. By 1923, the issue of rendition and detention without trial was attracting a great deal of critical attention as a result of the government's use of emergency powers at home to deal with Irish nationalists. During the war, courts had upheld the crown's power to deprive particular individuals of their liberty under very general delegated powers given by the Defence of the Realm Act, in cases such as $R v$ Halliday. The executive-minded approach found in these cases continued to be applied to detainees held in the United Kingdom after the end of the war, when Irish political prisoners challenged their detentions and deportations. It could be seen in the failure of Patrick Foy's attempt to secure his release from Wormwood Scrubs prison in London, where he had been sent after being arrested in Dublin under DORA Regulation 14B. The court rejected the argument that the power to detain him, which rested on a wartime provision allowing jury trials to be suspended in case of invasion or special military emergency, ${ }^{118}$ had ended with the signing of a peace with Germany four days before his detention. As Lord Reading CJ pointed out, the war would not be over for legal purposes until the King in Council had proclaimed it, and '[w]hen once the Court is satisfied that the proclamation was validly issued and that the war is still continuing, it has no power to interfere and to consider whether or not circumstances exist which justify the continuance of the proclamation. ${ }^{119}$ Similarly, Edward Brady failed in his attempt to challenge his detention in England in 1921 under the Restoration of Order in Ireland Act ('ROIA'), on the ground that that act had no application outside Ireland, and that the English Home Secretary consequently had no powers under it to detain and deport him. Both the Divisional Court and the Court of Appeal (by a majority) made a narrow (and controversial) interpretation of the legislation to find that the Act did apply in England. If the judgments in these cases appeared to rest on strict constructions of the powers conferred by legislation, it was

${ }^{117}$ Illustrated London News (London) 27 September 1924: 'The Idol of Modern Egypt: Saad Pasha Zaghlul'.

${ }^{118}$ Defence of the Realm Act 1915, sub-s 1(7).

${ }^{119} R v$ Governor of Wormwood Scrubs Prison [1920] 2 KB 305, 310, 36 TLR 432, [1920] 89 LJKB 759. For more information on the Irish cases discussed here, see David Foxton, Revolutionary Lawyers: Sinn Fein and crown courts in Ireland and Britain, 1916-1923 (Four Courts Press 2008) 299-302, 325-33, 344-70. 
clear that the judges' apparently technical interpretation of the law was deeply influenced by their political judgments about the powers needed to deal with Irish nationalists. ${ }^{120}$

However, these cases generated some disquiet about the extensive powers apparently retained by the executive to detain people without trial outside of war zones, ${ }^{121}$ and one month after Zaghlul's unsuccessful application to the Privy Council, the Court of Appeal in another Irish case signalled a change in approach, towards a more substantive understanding of the rule of law. The case was brought on behalf of Art O'Brien, secretary of the Irish Self-Defence League, who had long been a prominent Irish Republican in London, and who had become a supporter of the anti-treaty faction as Ireland descended into civil war, after the creation of the Irish Free State in 1922. ${ }^{122}$ At a time when the Irish government was worried that the Republicans might revive their guerrilla campaign with help from their supporters in England, the British agreed to arrest over 100 supporters and send them to the Irish Free State. O'Brien was arrested on 11 March, 1923 - two days after Zaghlul's case failed in the Privy Council - and removed to Mountjoy Prison in Dublin. The arrests and deportations generated an immediate political controversy. Having already been vocal in its support of Zaghlul, the Labour opposition raised the issue in parliament. The leader of the opposition, Ramsay MacDonald, questioned the use of Regulation 14B of ROIA, which 'applied to the disorderly situation in Ireland when it was in rebellion against us', and was not designed to deport English residents to the Free State, none of whose officials would be answerable for their actions in the United Kingdom. ${ }^{123}$

The detentions were challenged in Ireland and England. On Friday, 30 March, a habeas corpus

${ }^{120}$ As Lord Reading CJ put it in his judgment in the King's Bench Division, 'Here it is said that the whole of England is open to actions by people acting in support of the disorder in Ireland without there being any power to deal with them by executive action, and that they ought to be left outside until they commit crimes for which, when they are caught, they can be tried by a jury. I do not think that is at all a reasonable view to take of what Parliament was called upon to do under the circumstances when this Act passed': TNA TS 27/140, Trial transcript, p 65.

During argument, he had observed that the applicant's argument '[really] comes to this, that this flank is left open and these people can do as they like any day, and there is no executive power of dealing with it'. He added that while it might be true as a general rule that the ordinary processes of law could be used, 'you cannot forget all the things that have happened in England recently': Trial transcript, pp 46-7.

${ }^{121}$ After Foy's case, The Times (London) 25 March 1920 had written, 'It is hard to believe that Parliament intended to allow the Executive to refuse a trial in the Civil Courts to a British subject when the danger from foreign foes had disappeared.' On Brady's case, see (1921) 65 Solicitor's J 672 .

${ }^{122}$ Foxton writes, 'In London, membership of the IRB, the ISDL and the IRA was virtually interchangeable, Revolutionary Lawyers (n 119) 294. As Foxton shows, O’Brien was himself involved in litigation with the Irish government which sought to recover money said to have been misused by him: ibid 344.

${ }^{123}$ Parl Debs 5th ser, vol 161, col 1156. Sir John Simon told the house - on the basis of Brady that the Home Secretary's decision had been lawful, though he did not feel that he should have exercised his discretion in this way. 
application was made to the Irish Master of the Rolls, O'Connor, on behalf of Arthur Fitzgerald O'Hara, who wanted the court to make a declaration that ROIA and the regulations issued under it were void within Ireland and that the British Home Secretary's order was illegal. O'Connor felt that ROIA could not be enforced in Ireland, given the recent change in the constitution, but held that the military were entitled to hold the prisoners under martial law. ${ }^{124}$ An application for a habeas corpus was also lodged on behalf of O'Brien in England. The argument over the legality of O'Brien's detention turned on the effect on ROIA of recent legislation pertaining to the Irish Free State, and on whether this legislation had removed the power of the British authorities to order detentions in Ireland. Two acts passed in $1922^{125}$ had recognised both the Irish Free State's status as a dominion and the constitution passed by the Dail Eirann. A third $\mathrm{Act}^{126}$ empowered the crown to make any amendments to UK legislation necessitated by the establishment of the Irish Free State. The government clearly felt that the power to detain under ROIA had not been dislodged by the constitutional legislation, and to clarify matters further, it issued an Order in Council under the latter act on 27 March - after O'Brien's application had been made but before it had been heard - confirming that for the purposes of subsections 1(1) and 1(4) of ROIA, the words 'Ireland' or 'the British islands' included the Irish Free State. ${ }^{127}$

On 10 April the King's Bench Division refused to grant the rule for a writ of habeas corpus to issue. Lord Hewart CJ rejected the notion that ROIA was impliedly repealed when the conditions which gave rise to it ceased to exist, and held that 'Ireland' was a sufficient specification of the place of internment. He also held that the writ should not have been issued to the Home Secretary since he did not have physical control over the body of the detainee. ${ }^{128}$ The case then moved to the Court of Appeal where the Attorney General, Hogg, specifically drew attention to the recent Order in Council. In his view, the fact that the Free State was no longer governed by the British Cabinet might be a factor the Home Secretary should consider when choosing a place to intern prisoners, but it did not deprive him of the right. For O'Brien, Patrick Hastings KC invoked Magna Carta and the Petition of Right, as well as section 11 of the 1679 Habeas Corpus Act which prohibited the removal of detainees outside the kingdom. On this occasion, O'Brien was successful: the crown was ordered to produce him and make a return to the writ one week later. The three judges gave a number of reasons for holding the order to detain O'Brien in

${ }^{124}$ The Cork Examiner (Cork) 30 March 1923, 5-6, Irish Independent (Dublin) 31 March 1923. O'Connor MR had controversially granted a writ of habeas corpus in Egan v Macready [1921] 1 IR 265, in which he had held that the crown's prerogative powers regarding martial law were constrained by the statutory regime introduced by ROIA. However, in O'Hara's application, he held that in the absence of such legislation, the Irish executive's martial law powers were unconstrained. While refusing the conditional order, he gave the applicants liberty to serve notion of a motion on the Irish authorities. The case was eventually postponed pending the outcome of the litigation in England: Freeman's Journal (Dublin) 19 April 1923, 7; Foxton, Revolutionary Lawyers (n 119) 356-57.

${ }^{125}$ Irish Free State (Agreement) Act and the Irish Free State Constitution Act.

${ }^{126}$ The 1922 Irish Free State (Consequential Provisions) Act.

${ }^{127}$ In case any doubt remained, on 21 April (after the Divisional Court's decision) a further Order in Council made it clear that the same applied to regulations issued under ROIA.

${ }^{128}$ The Irish Times (Dublin) 11 April 1923, 6. 
Ireland to be ultra vires. For Bankes LJ, the corollary of the power to detain conferred by Regulation 14B was the power to release and to control the conditions in which the detainee was kept. In his view, the regulation therefore could not authorise the Home Secretary to transfer a detainee out of his power, and that being so, it was irrelevant whether or not the Free State was geographically an area in which a person could be detained. For Scrutton LJ, the English Home Secretary had never had the power under ROIA to intern in Ireland: only the Chief Secretary or Lord Lieutenant could do this, but their powers had ceased in 1922. ${ }^{129}$ For Atkin LJ, Regulation 14B had been repealed, as far as Ireland was concerned, by the Constitution Act, which enacted a constitution which provided that no one was to be detained except in accordance with law.

The reasoning of the judges in this case was not simply technical. As he had done in his dissent in Brady, Scrutton LJ made a particularly eloquent defence of the need to protect personal liberty from executive action, all the more so when the person whose liberty was being protected was not 'particularly meritorious'. ${ }^{130}$ O'Brien's case seemed to reaffirm a commitment to a substantive notion of the rule of law, after a period of executive-mindedness. How much of a turning point it was in the longer term is perhaps open to debate, for the decades which followed would see both executive-minded decisions as well as some more liberal ones. ${ }^{131}$ For present purposes, what needs to be emphasised is that the rule of law was not self-executing, with the common law able to be a neutral and ever present bastion of liberty. Rather, the interpretation of the law which was applied here owed much both to the liberal approach of the particular bench of judges who heard the case and to the broader political context which made this kind of rendition seem so offensive. For by 1923, it was evident that even those who were sympathetic to the government's position - such as David Lloyd George - found 'the deportation of British subjects to a dominion' to be beyond the political pale. ${ }^{132}$

\section{Control}

O'Brien's case takes us neatly to the second issue to be considered in habeas corpus cases, once it is clear that the detention is unlawful. For besides the issue of the legality of the order to detain, O'Brien's case also raised a question whether the writ could issue to someone who no longer had control of the detainee, having given custody to someone else who might be outside the court's jurisdiction. Since the purpose of the writ was to require the person who had custody of the detainee to produce his body in court, it was a sufficient return to the writ for the defendant to state that he 'has not the person in his possession, custody, or power'. Nonetheless, courts had long looked closely at whether there was any equivocation in the denial of custody,

${ }^{129}$ Scrutton also dismissed the idea that the British crown could by orders-in-council make valid laws within the territory of the Free State, and was highly critical of the most recent order in council: 'it adds a new terror to litigation with Government officials, if they can make Orders in Council while a case is being argued, to assist their argument': $R v$ Secretary of State for Home Affairs, ex parte O'Brien [1923] 2 KB 361 (CA) 390.

${ }^{130}$ It was 'one test of belief in principles if you apply them to cases with which you have no sympathy at all': ibid 382 .

${ }^{131}$ See below, 'Epilogue'.

132 Lloyd George in Parl Debs, 5th ser, vol 164, cols 898-99 (28 May 1923). 
given the importance for liberty of the writ. ${ }^{133}$ In what follows, we will explore how far the courts would go to require a person who had parted with control to produce the body. As shall be seen, courts in the era under study were often willing to go very far in order to ensure that the defendant, who had attempted to remove the person out of his own control and the control of the court, should produce the body. One reason for this was that the cases which defined the law in this area did not turn on the custody of political prisoners, but the custody of children, whose souls were being battled over by rival religious agencies. However, as would be seen in O'Brien's case, principles developed out of child custody cases could also be applied in political ones.

\section{Margaret Aylward's Imprisonment}

This issue first came before the courts both in England and Ireland in the late 1850s, when there was a high level of anxiety in both countries about proselytism. The attitude of the English courts towards religious bodies who sought to obstruct the recovery of children was stated by Lord Campbell in 1859: 'the writ of habeas corpus was sacred,' he said, 'and must not be trifled with, and if there were any reason to believe that it was [not] honestly and implicitly obeyed, the court would inflict condign punishment upon the party who attempted to evade the law of the country.' In the case before him, $R v$ Roberts, a Catholic priest was ordered to be gaoled on an attachment, after he had failed to produce a girl who had returned to his school in defiance of her Protestant father, and had stated that he had no knowledge of her whereabouts. ${ }^{134}$ At the same period, the issue of sectarian 'kidnappings' assumed a much higher profile in Ireland. In the aftermath of the Famine, Protestant philanthropists set up schools and orphanages for poor and orphan Catholic children with a view to converting them. In response to this, the Catholic community set up its own voluntary associations. The competition for souls was intense, and accusations soon abounded that children were being 'kidnapped', and removed from the control of their parents. These disputes soon generated litigation, ${ }^{135}$ and a number of habeas corpus cases came to court, to recover the custody of children who had been secretly removed from those who wanted to place them in Protestant schools. In these cases, the Irish courts showed as tough-minded an approach to the question of control as Lord Campbell had.

This approach can be seen in the litigation over the four children of Eleanor Sherwood. They were put on a train in Dublin on 14 March 1860, on their way to a Protestant orphanage near Galway. During the journey, they fell into conversation with two men travelling in the same

\footnotetext{
${ }^{133}$ If the return stated 'I had not at the time of receiving this writ, nor have I since had the body of AB detained in my custody,' it was insufficient, since it did not challenge the defendant's control: see Rex v Winton (1792) 3 TR 89; cf Rex v Lord Mayor of London (1675) 2 Levinz 128. ${ }^{134}$ Reg $v$ Roberts (1860) 2 F \& F 272. He was released one day later when the girl had been returned to her father.

${ }^{135}$ The first salvo in the litigation was said to be the battle in Chancery in 1858 for custody of the orphaned children of John O'Malley, a lapsed Catholic constable of Tuam: the proceedings can be traced in Tuam Herald (Tuam) 21 August and 4 September 1858, 12 May 1860; Freeman's Journal (Dublin) 15, 16, and 22 November 1858); Connaught Telegraph (Castlebar) 1 December 1858; Belfast Newsletter (Belfast) 8 May 1860.
} 
carriage, on their way to the Galway Assizes. On discovering that they were Catholic orphans, these men - Thomas James M'Robins, a lawyer who was also Chairman of Roman Catholic Dormitory in Townsend Street, Dublin, and his client Denis O'Connor - decided to return the children to Dublin. Evading the matron of the orphanage who had come to meet them, they took the children to a lodging house in Galway owned by John O'Connor, where M'Robins made arrangements for their removal. On the following day, their mother arrived in Galway and went to look for them at the lodging house. Having been refused access, she obtained a writ of habeas corpus from Justice Hayes, addressed to both O'Connors. In their returns, made on 20 March, they stated that they did not have any control over the children, and did not know where they were. The returns were adjudged insufficient, and the two men were told that a writ of attachment would issue against them in ten days time unless cause was shown. On 22 March, M'Robins - who had himself drawn up the returns - took the children back to Dublin, handing them over to Catherine Davis (a cousin of the children's father), and Ellen Blake (their grandmother). The children were later taken from these women by a man claimed by their mother to have been a Catholic clergyman. ${ }^{136}$ With the children still missing, habeas corpus proceedings were taken against all the parties involved, and attachment orders were issued against the O'Connors, M'Robins, Davis, and Blake, in order to force them to divulge what they knew about the whereabouts of the children. With no information forthcoming, they were all put in the custody of the Marshal of the Four Courts Marshalsea. All but M'Robins - the main mover in the affair - were released after Ellen Blake's death in custody in November. He was finally discharged in April 1861, by which time it had become apparent that the children were in the custody of their paternal family. At this final hearing, the court accepted that M'Robins had now no control whatever over the children, and considered his six months' imprisonment as sufficient punishment for his contempt in obstructing the writ of the court. Although all five defendants were gaoled for failing to make an adequate return, it is clear that none of them (save perhaps John O'Connor) had actual control of the children at the time the writ issued against them. However, this was not an issue of concern to the courts, which were convinced that the defendants at least had the knowledge to trace the children and secure their return. Indeed, there was little doubt in either the Catholic or Protestant Press that the children had not been had been taken by a complete stranger and were untraceable. ${ }^{137}$

Another case resulted in the imprisonment of one of the most prominent campaigners, Margaret Aylward, the founder of St Bridget's Orphanage in Dublin. ${ }^{138}$ The case concerned Mary

\footnotetext{
${ }^{136}$ The details are taken from the following press sources: Belfast Newsletter (Belfast) 24, 25, and, 27 April 1860, 3, 4, and 7 May 1860, 7, 8, and 17 November 1860; Freeman's Journal (Dublin) 9 May 1860, 24 April 1861; Leinster Express (Maryborough) 1 December 1860. ${ }^{137}$ Reporting that Sherwoods' mother had sold them to a 'Souper depot' run by Protestant proselytisers, the Connaught Telegraph wrote that 'every Catholic feels it his bounden duty to thwart their proceedings A LA 'Mac' and ' $\mathrm{O}$ ' or in whatever other way circumstances dictate': 'The New Phase of Fanaticism', Connaught Telegraph (Castlebar) 16 May 1860. By contrast, the Belfast Newsletter noted that the court's firm line would 'have the effect of spoiling the sport of the Romish kidnappers.'

${ }^{138}$ On Miss Aylward, see Margaret H Preston, Charitable Words: Women, Philanthropy and the Language of Charity in Nineteenth-Century Dublin (Praeger 2004); Maria Luddy, Women and
} 
Matthews, who had been sent to Miss Aylward's orphanage in April 1858 by Mrs Mary Jordan after she had been asked by the girl's dying father to ensure that she be raised a Catholic. The child's mother was a Protestant, who had left her family to work as a servant in the West Indies, but after being dismissed from her job, she returned to Ireland and sought custody of her child. On 28 May 1858, she obtained a conditional order for a habeas corpus to be issued against Mrs Jordan. Having discovered from Mrs Jordan's affidavit that she had given the child to Miss Aylward, Mrs Matthews went to the orphanage, on both 4 and 5 June, but was refused entry. On 10 June, she obtained a conditional order for a habeas corpus directed to Miss Aylward, who responded in an affidavit six days later that she considered Mrs Jordan to be the legal guardian, appointed by the child's father. She added that she had placed the child with a nurse seven miles from Dublin on 3 April, but 'for obvious reasons' declined to reveal the name of the nurse unless ordered to do so by the court.

Proceedings were delayed, pending the outcome of another case, In re Moore, where a widowed Catholic mother attempted to recover custody of the child she had given to a Protestant orphanage, and where the mother's legal rights had been challenged. ${ }^{139}$ In the meantime, the defendants drew up affidavits stating that on 8 June 1858, a strange woman had come to the nurse's house, with a forged letter, purportedly written by Miss Aylward, asking for the child to be given to her. The girl apparently knew the woman with the note, and went away quite happily. This had only come to Miss Aylward's attention (the affidavits claimed) on 19 June, when the nurse, Elizabeth Kenny, visited her. This was to suggest that the child had disappeared without trace, through no fault of Miss Aylward's. ${ }^{140}$ When the case returned to court in November 1859, emphasis was put on her lack of control and her consequent lack of means to obey any order to produce the child. However, Mrs Matthews' counsel poured scorn on the story of the forged note, and pointed out that even though she had apparently made the discovery only three days after submitting her affidavit in reply to the conditional order, Miss Aylward had not taken any steps either to recover the child in the intervening period, or to alert the authorities about her disappearance. Holding that the affidavits were not a sufficient answer, the court made the conditional order absolute. Despite her apparent disappearance, Miss Aylward was regarded as

philanthropy in nineteenth-century Ireland (CUP 1995); Jacinta Prunty, Margaret Aylward, 1810-1889: Lady of Charity, Sister of Faith (Four Courts Press 1999).

${ }^{139}$ In the matter of John alias John Edward Moore, an Infant (1859) 11 Irish Common LR 1. In this case, the Queen's Bench was divided, with the Catholic Justice O'Brien holding that where no testamentary guardian had been appointed, the mother, as guardian by nurture, was entitled to custody, unless she had been guilty of gross immorality or cruelty. The Protestant Chief Justice Lefroy however held that the court could decline to grant custody where the applicant had not acted in good faith (building on Lord Campbell's obiter comments in Reg v Maria Clarke, in re Race (1857) 7 E \& B 186, 200). In his view, she had not acted in good faith, having claimed to be a Protestant.

${ }^{140}$ The parties sought to file in these affidavits in April 1859, in order to have the case dismissed the case, but the court refused to deal with it until the case had come on for a hearing. As Chief Justice Lefroy put it, 'We must see whether any effort has been made to intercept the power of the Court by any trick or contrivance': Belfast Newsletter (Belfast) 29 April 1859, 3; In the Matter of Mary Matthews, an Infant (1859) 12 Irish Common LR 233, 270-71. 
still being responsible for the child. '[I]t would be a perfect absurdity,' Chief Justice Lefroy ruled, 'to doubt the legal responsibility of a person who, taking the custody of a child, without the consent of the guardian, and thereby rendering herself answerable to the guardian, can divest herself of that responsibility, by transferring the child to the custody of another. ${ }^{141}$ Whether the apparent subsequent abduction of the child would be a sufficient answer would be discussed when they saw her return. Hayes J agreed, adding, 'The writ must go, else this Court might be completely baffled in its protection of the liberty of the subject. ${ }^{142}$

The case returned to court in April 1860, when Miss Aylward made a return stating that she had neither control over the child nor the means of procuring her body. The court divided on sectarian lines over whether the return was sufficient. The Catholic O'Brien J held that the return was sufficient both in law and in fact. As a matter of law, she did not have to explain how she came into custody of the child, and how it left her possession, since she denied having custody at any point since the writ issued, nor was there any factual evidence to contradict her affidavit, and it was not incumbent on the person making the return to prove the truth of statements contained in it. O'Brien also stressed that the object of the writ was 'not to recover damages, or make that party responsible if the child went missing after the defendant had refused to hand it over', but simply to require a person detaining another to produce her. ${ }^{143}$ The two Protestant judges disagreed. Hayes $\mathbf{J}$ held that the return was insufficient in law. Having admitted the original taking of Mary, it was incumbent upon her to show the court what had become of the child once in her custody. ${ }^{144}$ In his view, Miss Aylward had made herself responsible for the child when she deliberately and wrongfully refused to recognise the mother's legal rights. Hayes clearly suspected that there had been connivance here, but in any case, she could not 'found a legal excuse upon a misfortune which resulted from her own misconduct and neglect'. ${ }^{145}$ He compared her liability with that of defendants in trover, who had transferred the plaintiff's goods to a third party. Lefroy CJ agreed. For him, the central question was not whether she now had control, but whether she had had control on 10 June, when the conditional order issued. Although she claimed that the child had already been taken by the stranger, looking at the facts of the case, he did not believe that the child could have been removed without her collusion. Citing Lord Campbell's dictum in Roberts with approval, he concluded that this was not an 'honest and implicit' obedience to the writ.

An attachment was issued, but Miss Aylward was allowed to tender bail to answer interrogatories. ${ }^{146}$ After the submission of voluminous answers, the case returned to court in

\footnotetext{
${ }^{141}$ In the Matter of Mary Matthews, an Infant (n 140) 238.

142 ibid 241.

143 ibid 264. O'Brien's stance attracted the attention of the Protestant press, who accused him of seeking to shelter Catholic kidnappers: 'Romish kidnapping', Belfast Newsletter (Belfast) 8 May 1860.

${ }^{144} \mathrm{He}$ agreed with the doubts of Gould $\mathrm{J}$ in $R v$ Wilkes (1763) 2 Wils KB 151, 154, who (unlike his brother judges) felt that the return of the king's messengers that Wilkes was no longer in their custody (after he had been transferred to the Tower) was not sufficient.

${ }^{145}$ In the Matter of Mary Matthews, an Infant (n 140) 250.

${ }^{146}$ In Rev Roberts' case in England, the court had also suspended the attachment for a day in
} 
June. This time the court was unanimous. The additional evidence revealed since the April hearing convinced all members of the court that Miss Aylward and Mrs Jordan had been acting together to 'baffle' the authorities. Miss Aylward knew that the mother of the child would seek to recover her (having been warned of this by Mrs Jordan's priest), and had consequently changed the child's name to Mary Farrell. She had seen the writ served on Mrs Jordan, and had her lawyer draft the answering affidavit, creating a delay during which time the child went missing. In these circumstances, the writ issued to Mrs Jordan could be taken to have been served on her. O'Brien $J$ still felt some doubt over her liability in a habeas corpus case for the subsequent abduction of the child (which he accepted she did not authorise), but he held that her conduct in not disclosing the abduction of the child after the writ was served on her was a contempt. Her conduct was designed 'by anticipation to frustrate any order which the Court might make for the delivery of the child to the mother. ${ }^{147}$ Miss Aylward was not gaoled immediately but was given bail, ${ }^{148}$ though the court did impound the case papers, with a view to prosecuting her for felony. However, any hope that the child would be produced as a result of these threats, as it had been in the Roberts case, proved unfounded. When the case returned to court in November, Miss Aylward's lawyer declared that she had no means of locating the child, and had satisfied her conscience that she had done nothing wrong. On this occasion, the court ruled that she be gaoled for six months. ${ }^{149}$ Her case continued to remain prominent in the public press. ${ }^{150}$ Her supporters set up the St Bridget's Defence Committee to raise funds for the costs of the case, and continued to debate the merits of the case. ${ }^{151}$ She was eventually released, returning to her philanthropic activities, and continuing her campaign against what she considered Protestant proselytism. Mary Matthews was never returned to her mother (or her Protestant supporters) and it later turned out that the child had been sent overseas. ${ }^{152}$

order to allow him to into recognizances to answer interrogatories regarding his contempt, but he was imprisoned having refused this. The Times (London) 31 May 1859, 9.

${ }^{147}$ In the Matter of Mary Matthews, an Infant (n 140) 285.

148 This led to outraged comments in the Protestant press: Leading article, Belfast Newsletter (Belfast) 14 June 1860, 2.

149 'The Queen at the prosecution of Mrs Maria Mathews v Miss Margaret Aylward. The Kidnapping case', Irish Times (Dublin) 7 November 1860. For press reactions, see also Belfast Newsletter (Belfast) 10 November 1860; Tuam Herald (Tuam) 10 November 1860. There was suspicion that the decision had been influenced by sectarian views among the judiciary, although the final decision was made by a mixed bench of Protestant and Catholic judges. See Prunty, Margaret Aylward (n 138) 93.

${ }^{150}$ Litigation over her incarceration continued: though the court had sentenced her to be gaoled in the Richmond Bridewell, she was moved to the Grangegorman Female Penitentiary, since the former was a men's prison. A habeas corpus was consequently sought for her release, on the grounds that the court had no power to send her to this gaol for contempt of court; but the application failed. Irish Times (Dublin) 27 Nov 1860; Freeman's Journal (Dublin) 1 December 1860, 4; Belfast Newsletter (Belfast) 3 December 1860, 3.

${ }^{151}$ Freemans Journal (Dublin) 11 January 1861, 3; 12 January 1861, 3. Meanwhile the Protestant press complained that she was being given favourable treatment in prison. Belfast Newsletter (Belfast) 21 March 1861, 3.

152 Prunty, Margaret Aylward (n 138) 92. 


\section{Dr Barnardo's Attachment}

These cases demonstrated that Irish courts would go far to check whether defendants retained effective control over a person being sought, and showed that they were prepared to imprison people for contempt who were perceived to obstruct the recovery of that person. The question of how far English courts would go was resolved in the 1890s when the sectarian war over the souls of orphaned children that was being waged between Dr Thomas Barnardo and the Catholic Bishop of Salford, Herbert Vaughan, found its way into the House of Lords. Vaughan was concerned that the numerous Protestant bodies providing homes for orphaned and destitute children were proselytising agencies bent on the conversion of Catholic children, and helped set up a Catholic Protection and Rescue Society in 1886 to prevent the children of Catholic parents being taken into Protestant institutions. ${ }^{153}$ The Salford-based society began its campaign with an (unsuccessful) attempt to prosecute an officer of the Manchester and Salford Boys and Girls Refuge for abduction, but found that writs of habeas corpus were more effective tools. ${ }^{154}$ Barnardo, the publicity-hungry founder of the famous Homes for Orphan and Destitute Children, had grown up in Dublin and been inspired by the work of Protestant philanthropists there. He was also fiercely anti-Catholic, ${ }^{155}$ and determined to resist any habeas corpus applications brought by Catholic litigants demanding the return of their children. ${ }^{156}$

Barnardo was prepared to use all kinds of tactics to prevent children falling back into Catholic hands. Mothers were told that they had signed binding agreements, that they had no rights over illegitimate children, or that they were simply unfit to look after their child. It was not an argument which convinced the courts, ${ }^{157}$ and led to strong criticism of his methods. ${ }^{158}$ An even

${ }^{153}$ In 1889 , the bishop stated that he had intervened in 31 cases in two years to secure the rights of Catholic parents against philanthropic institutions which did not recognise their religious rights: Pall Mall Gazette (London) 28 February 1887, 2; The Times (London) 10 June 1889; cf The Times (London) 4 May 1892, 6. There were said to be 37 Protestant homes in Manchester and Salford, and the five leading ones contained 155 Catholic children: Leeds Mercury (Leeds, 21 February 1887) 4. For the society’s origins, see JG Snead-Cox, The Life of Cardinal Vaughan (Burns Oates \& Washbourne 1934) ch 9.

${ }^{154}$ Manchester Times (Manchester) 18 December 1886, 3. The habeas corpus application succeeded: Birmingham Daily Post (Birmingham) 21 February 1887, 4.

155 'The Roman Catholics and My Children' (1889) 13 (ns) Night and Day 122.

${ }^{156}$ See eg In re Brooks, The Times (London) 23 July 1889, 12, where he was ordered to hand back a child. The court held that the mother had the right to the custody, unless there was a risk the child would be injured. Barnardo later claimed to have won a case involving two girls, on those grounds: (1889) 13 (ns) Night and Day 125. See also Ex p Murphy, The Times (London) 14 June 1890; Pall Mall Gazette (London) 1 August 1890.

${ }^{157}$ See eg his detailed investigations into the moral character of the Catholic mother of John Jones, Margaret McHugh, in the affidavits in TNA KB 1/314/2 and in The Times (London) 19 April 1890, 5. For the trial proceedings, see The Times (London) 8 May 1890, 3; 16 May 1890, 3; 17 May 1890, 7; Queen v Barnardo; Jones's Case [1891] 1 QB 194; Barnardo v McHugh [1891] AC 388, 393. 
more controversial tactic was to move children to inaccessible places. In two cases, anticipating a writ of habeas corpus from Bishop Vaughan's lawyers, Barnardo gave children to strangers to take them out of the country. The first case concerned Martha Ann Tye, who had been found wandering the streets of Bristol. In July 1888, her mother agreed to entrust the child to Dr Barnardo's Homes for two years. However, at the end of the year, and having remarried, she sought her daughter's return, so that she could be given a Catholic education. Sensing Vaughan's involvement, and anticipating legal proceedings, Barnardo acted quickly. On 21 December, the day when his solicitors met the mother to discuss the issue, the child was handed over (without the mother's knowledge) to a Mme Gertrude Romand, a French-Canadian who took the child first to Europe and then to Canada. ${ }^{159}$ In January 1889, the mother obtained a writ of habeas corpus, which gave Barnardo until 30 April to produce the child. In his return to the writ, Barnardo stated that Mme Romand had refused to return the child, or to say where she could be found. ${ }^{160}$ Justice Mathew did not accept Barnardo's argument that he had no control over the child, and condemned the return as 'evasive and unsatisfactory'. An attachment was issued, although its execution was delayed to allow Barnardo to answer interrogatories 'to compel him to state fully and frankly on oath all that can be known about the child, so that the mother may have a chance of getting her back. ${ }^{161}$ Barnardo appealed, but the Court of Appeal confirmed that the facts stated in his return - that he had parted with the custody of the child and could not get her back - were not an excuse for non-compliance with the writ and held (following the line taken in Margaret Aylward's case) that the attachment had to issue. ${ }^{162}$ The court did not accept that the fact that he had disposed of the child before the writ issued excuse him from liability to the writ, for the judges took the view that he had acted unlawfully in parting with the custody of the child before the writ issued. 'Persons who illegally put a child out of their power do so at their peril,' Lindley LJ explained, 'and, if they are ordered to produce the child, no excuse founded on their own inability to comply with the order will be held a sufficient answer to the

${ }^{158}$ However, he did obtain legislation empowering a court to refuse to deliver a child to the parent who had abandoned or deserted it, or allowed it to be brought up at another's expense, if it was not satisfied that the parent was a fit person to have its custody. This act helped Barnardo resist parental attempts to recover children from his homes. Gillian Wagner states that it enabled him 'to frustrate more than eighty attempts by parents to regain custody of their children in the years that followed': Barnardo (Weidenfeld and Nicolson 1979) 234. However, at the same time, the act did protect the child's religious rights, and prevented proselytizing.

${ }^{159}$ Justice Mathew suspected he knew what he was doing: he said 'My experience at Chambers has informed me that such applications against him have been made, and he well knows the law and consequence of his not giving up the child... I think that he is brought occasionally under the influences of a sectarian character ... which may lead him occasionally into violation of the law': In the matter of Martha Ann Tye, an Infant, and of an application by Margaret Ward, her mother (1889) 5 TLR 497, 498.

${ }^{160}$ His return also stated that she had entered an agreement not to remove her daughter without consent, while also consenting to the placement of the child anywhere within the empire.

${ }^{161}$ Justice Grantham added, 'he must have means of finding where the child is': In the matter of Martha Ann Tye (n 159) 501.

162 The Queen v Barnardo (1889) 23 QBD 305. Cotton LJ in this case (at 314) referred to Re Matthews as 'a valuable decision'. 
writ. $^{, 163}$

The decision in Martha Tye's case unleashed a series of applications by parents for the custody of their children. ${ }^{164}$ The most prominent involved another child sent to Canada, Henry Gossage. ${ }^{165}$ The application was brought by his mother, Mary Ford. Originally from Leamington, the boy had (according to Barnardo) been sold by his drunken and dissolute mother to two organ grinders, with whom he had tramped around the country for four months. They had abandoned him in Folkestone, where he had been found before being handed over to Barnardo on 25 September 1888. Although the boy's mother had never signed the standard agreement with Barnardo's homes, she had indicated that she would be pleased if he kept her son. However, on 10 November, Barnardo received a letter from Alfred Newdigate from Leamington, ${ }^{166}$ written on behalf of the (illiterate) mother, who wanted the child to be put into a Catholic home, St Vincent's Home on Harrow Road. On the same day that this letter was written, Barnardo first met William Norton, a Protestant Canadian, who told him he had lost his son and wanted another to adopt. ${ }^{167}$ On 16 November, he entrusted the boy to this unknown Canadian, having seen only a letter of recommendation from an unknown Presbyterian minister, whose name Barnardo could not recall. ${ }^{168}$ Furthermore, Norton refused to disclose his address, since he claimed that it was common for birth parents to seek to obtain the return of their children in Quebec, something he wanted to avoid.

163 ibid 316. See also the report in The Times (London) 16 July 1886, 3; 17 July 1889, 3. After Barnardo failed to produce the child, and attachment proceedings were commenced, he was then examined on interrogatories by the Master of the Crown Office, in which he testified what steps he had taken to trace the child. Proceedings were suspended in this case, pending the outcome of Barnardo's appeal to the Lords in the Gossage's case (discussed below). The Queen v Barnardo in The Times (London) 12 March 1890, 3. Given the outcome of Barnardo v Ford in the Lords, nothing further was done in this case.

${ }^{164}$ See The Times (London) 18 and 19 December 1889, 3 February 1890; The Standard (London) 1 February 1890; Lloyds Weekly Newspaper (London) 13 July 1890.

${ }^{165}$ For another 'Canadian' case, see In the matter of Peter and Mary Ann Corless, The Times (London) 23 July 1889, 12.

${ }^{166}$ Newdigate was a Poor Law guardian, and was a committee member of the Charity Organisation Society in Leamington (a society which was very sceptical about Barnardo's work). He had previously arranged the emigration of her two other sons to Catholic homes in Canada. See the letter of Isabella Bacchus, Daily Telegraph (London) 5 February 1890. See also his affidavits in TNA KB 1/314/1.

${ }^{167}$ Barnardo had for many years sent children to Canada, through homes he had set up in Ontario. See Wagner, Barnardo (n 158) ch 11. Where mother signed the standard agreement, which included a clause giving permission to send the child to any place in the United Kingdom, her colonies or dependencies, or Europe, the Home Office was not minded to intervene when children had been sent without their mothers' knowledge to Canada: see the case of Mary Ann Giles in TNA HO 144/310/B6159.

168 The details of the case were related by Barnardo in (1889) 13 Night and Day. Newdigate wrote a letter to The Standard on 5 December 1889, disputing that she had 'sold' the boy. The mother also denied receiving money: see her affidavit of March 1889, in TNA KB 1/314/1. 
Although Newdigate was sent a formal acknowledgment of a donation he had given, no reply was sent to his request for the child. Nor was a reply sent to Douglas Hope, of St Vincent's, who had written about arrangements relating to the boy, until the middle of December, when a note was sent simply declining to comply with his request. When Newdigate wrote again on 22 December, a reply was sent stating that Dr Barnardo's homes were 'not designed for proselytizing purposes' and that children would not be returned on religious grounds. No mention was made that the child had been removed to Canada. Only on 8 January 1889 (in the face of threats to bring a writ of habeas corpus) was a letter sent stating that the boy 'is not and has not been for a considerable time an inmate or under the control of the Managers of these Institutions.' When the application for a habeas corpus was made in March, Mathew J refused it, this time accepting Dr Barnardo's statement that the child was out of his custody and control. However, on 30 November (after the decision in Tye), the Queen's Bench Division ordered that the writ should issue. As for Barnardo's claim that he could not produce the child, Lord Coleridge said: 'You must produce him. You had no business to get rid of the child, and therefore the law deems the child to be virtually in your custody. ${ }^{169}$ Barnardo took his case to the Court of Appeal, which confirmed that the writ should issue. Lord Esher also took the opportunity to explain the court's earlier decision in Tye. The court had not, he pointed out, decided in that case that habeas corpus could be used 'merely for the purpose of punishing a past illegality' if it was utterly impossible for a child to be returned (for instance, if it had died). However, they took the view that unless 'such absolute impossibility was clearly shewn,' it was no excuse to say that, as a result of his own illegal action, it had become 'extremely difficult or almost impossible' to produce the child: in such cases, the court would insist that he 'do everything that mortal man could do in the matter' until it was clear that the child's return was 'an absolute impossibility'. ${ }^{170}$

Barnardo again challenged the decision and in July 1892, the appeal finally reached the House of Lords. ${ }^{171}$ The Lords rejected the view of the law stated in Tye's Case, that the writ could be used against a person who had unlawfully removed someone from their custody. Lord Watson was particularly critical of Lindley LJ's formulation. The writ, he noted, was intended to facilitate the release of persons in unlawful detention, and was not the vehicle to inflict penalties on those who had at one time or another illegally detained them. In his view, to order a person who had unlawfully parted with the custody of a child to recover it for the court would necessitate the employment of 'agents and detectives, and application for the assistance of foreign Courts, which, in my opinion, are neither more or less than penalties imposed in respect of his breach of

\footnotetext{
${ }^{169}$ He was not clearly not impressed with Barnardo's behaviour in handing the boy over to a complete stranger: see In the matter of Henry Gossage, an infant, and an application by his mother for a writ of habeas corpus to Dr Barnardo in The Times (London) 2 December 1889, 3. ${ }^{170}$ The Queen v Barnardo; Gossage's Case [1890] 24 QBD 283 294-95.

${ }^{171}$ There was a good deal of criticism in the press over the length of time and the expense involved in this case. The Times (London) 26 July 1892, 9 regretted 'the waste of funds that are intended for the rescue of waifs and strays', but also regretted Barnardo's uncandid and misleading correspondence.
} 
duty. ${ }^{172}$ Lord Herschell agreed that the writ could not be used as a method of punishing a person who had parted with the custody. Lord Halsbury also took this view, though he added that the court had to look very closely where it suspected that 'a counterfeited release has taken place, and a pretended ignorance of the place of custody or of the identity of the custodian is insisted on'. ${ }^{173}$ This was to confirm Lord Esher's explanation that the writ could not be used as a punishment for a past wrong (as Lindley LJ's dictum seemed to imply), but it could be used to test whether the defendant had any real ability to return the person.

Barnardo v Ford thus settled the point that the writ of habeas corpus could only be used to order a person to produce the body of a person under his control at the time the writ issued. It could not be used to punish a person who had acted unlawfully before that moment. To impose punishment, one needed a criminal trial, with the appropriate criminal penalties. This aspect of the decision came in for some criticism from the Law Quarterly Review, which noted that while the Court of Appeal's use of the writ in Tye may have been novel, 'some of the most admirable portions of English law have been created by judges who have known how to employ old forms for new purposes'. The journal felt that the Lords had checked an innovation calculated to give effect to the spirit of the law, and 'really to ensure that respect for personal liberty, the securing whereof is the end for which the writ of habeas corpus exists. ${ }^{, 174}$

However, the Lords' decision was not the end of the matter for Dr Barnardo. For while the Lords disapproved of the law as stated in Tye, they agreed that the applicant was entitled to the issue of the writ, so that the disputed facts about the degree to which Barnardo in fact had control could be more fully investigated on the return. The writ was issued and Barnardo made his return in November. ${ }^{175}$ The return stated that Henry Gossage had not been in Barnardo's 'custody, power, or control' since 16 November 1888, and that Barnardo had had no communication with William Norton since that date. He stated that he had 'by employing skilled detectives' sought to trace the boy, 'but I have been hitherto unable to discover him or to obtain intelligence or information about him. ${ }^{176}$ Nor was this the end of the matter, for the applicants traversed the return, and the court gave time for further affidavits to be filed to investigate the truth of the matter. ${ }^{177}$ The matter itself was not determined until May 1893, when the case came before Baron Pollock and Hawkins J. This time, Dr Barnardo was required to supplement the information in his affidavit by giving oral evidence in court. In the end, the judges accepted that the return was a true one that Dr Barnardo was as a matter of fact unable to do anything more to return the boy. But they were far from happy. Hawkins J was 'extremely suspicious as to the truth of the return', and was

\footnotetext{
${ }^{172}$ Barnardo v Ford [1892] AC 326 334-35.

173 ibid 333.

174 (1893) 3 LQR 8-9. The author was probably the journal's editor, Frederick Pollock.

${ }^{175}$ Barnardo also gave his own commentary on the Lords' decision in an article in Night and Day, claiming the judges had been 'hoodwinked'. Since the matter was still sub judice, Barnardo was fined $£ 25$ and costs were imposed: The Times (London) 26 November 1892, 7; 29

November 1892, 13.

${ }^{176}$ The Queen v Barnado; In the Matter of Gossage, An Infant, The Times (London) 2 November 1892, 3.

${ }^{177}$ The Queen v Barnardo (Re Gossage), Daily News (London) 8 November 1892.
} 
far from convinced even of the existence of William Norton. However, both judges accepted as true that Barnardo had handed the boy over to a person who could not be traced. ${ }^{178}$

As this history shows, in Dr Barnardo's case, the courts made repeated attempts to test whether his assertions that he had no de facto control were true. ${ }^{179}$ Rather than simply accepting the words in his return to the writ that he had no control, the court sought to test the truth of the return, just as they had in Margaret Aylward's case, by further examinations of both documentary and oral evidence. ${ }^{180}$

\section{Art O'Brien's Return}

Barnardo's case was much in the minds of the Court of Appeal judges when dealing with O'Brien's rendition. There was an apparent paradox in the case. On the one hand, it was argued that the fact that the Home Secretary had deprived himself of control over O'Brien showed that the order was ultra vires; on the other hand, he was seeking a writ of habeas corpus, which was premised on the assumption that the Home Secretary had control. But in fact, Atkin LJ ruled, there was no dilemma:

In testing the validity of the order the question is as to the legal right to control; in testing the liability of the respondent to the writ the question is as to de facto control. In all cases of alleged unjustifiable detention, such as arise on applications for the writ of habeas corpus, the custody or control is, ex hypothesi, unlawful: the question is whether it exists in fact. ${ }^{181}$

Indeed, although it had been argued in court that the Home Secretary did not control O'Brien's body, the government had already given assurances in the House of Commons that the Irish had agreed that the men could apply in person to the Advisory Committee appointed to monitor their detention, and to release them if that committee recommended it. They had also agreed that the men would not be charged with any criminal offence without the consent of the British. It was evident that there was very close co-operation between the two governments. Although in his affidavit to the court, the Home Secretary denied having control over the body of O'Brien, he

${ }^{178}$ The Queen v Barnardo, The Standard (London) 19 May 1893.

${ }^{179}$ According to Justice Wilmot's 1758 opinion (Wilm 107), judges were bound by the facts as stated in the return (unless there was a judgment on demurrer or the verdict of a jury in an action for a false return) since they had no power to weigh such questions of fact. In practice, even in Wilmot's day, judges tested questions of fact (notably by considering affidavits on rules nisi), and after the 1816 Habeas Corpus Act, judges were allowed to examine the truth of the return by considering affidavits, in cases where the applicant was detained 'otherwise than for some criminal or supposed criminal matter'. This provision was designed 'to except all cases of proceedings at law, and to include merely cases where parties are detained without any authority': Carus Wilson's Case (1845) 7 QB 984, per Patteson J.

${ }^{180}$ Lord Herschell had confirmed in the Lords that Barnardo could be cross examined on the return: Barnardo v Ford (n 172) 340.

${ }^{181}$ Ex parte O'Brien (n 129) 398. 
subsequently told the Commons that this only meant that he had no control over his treatment in the Mountjoy Prison, 'but on all other points I had essential control'. ${ }^{182}$ There was also continuing correspondence between the two governments on how to make arrangements for O'Brien's transportation in case of an adverse verdict. Indeed, on the day of the Court of Appeal's judgment, the Home Secretary sought confirmation from the Irish that they would indeed hand him over - 'in view of possible questions in Parliament'. ${ }^{183}$

Although Atkin LJ in his judgment had indicated that the court would consider the question of whether the Home Secretary had in fact lost control when the return was made (as had been done in Barnardo's case), the government took the words in the writ that the body had to be produced along with a return to the writ literally. ${ }^{184}$ As far as the government was concerned, everything therefore hinged on the outcome of an appeal to the House of Lords against the decision to issue the writ. During the brief five-day interval between the two sets of hearings, it was decided to bring O'Brien back to England, so that he could be released if the appeal failed. ${ }^{185}$ Unlike Barnardo and others before him, they did not plan to continue the battle when the time came to make a return to the writ by arguing the impossibility of returning him. ${ }^{186}$ Equally, even though the Home Office drew up an order under ROIA authorising his detention in Brixton Prison on his return, they were not inclined to argue on the return that he was now lawfully in detention, under an amended 14B order. Consequently, even though they were disappointed by the Lords' decision that they did not have the jurisdiction to hear the case, ${ }^{187}$ O'Brien was produced in

${ }^{182}$ Parl Debs, 5th ser, vol 164, col 868 (28 May 1923).

${ }^{183}$ Note from Sturgis to Loughnane, TNA HO 144/3577. On the day of the Court of Appeal's judgment, the Irish government assured the British that 'We gave the undertaking previous to apprehension. We will carry it out when requested.': Telegram of 9 May 1923.

${ }^{184}$ The notice served with the writ ordered the Home Secretary to have Art O'Brien's body before the court at 10.30 am on 16 May 1923 'or in default thereof the said Court will ... be moved for an attachment against you for your contempt in not obeying the said Writ': TNA HO 144/3577. At the Cabinet meeting on 16 May, it was noted that the order was that the Home Secretary had to produce him: TNA CAB 23/45/26.

${ }^{185}$ The decision to bring him to England was made on 11 May. The Court of Appeal had ordered that the body should be produced in court and a return made on 16 May: TNA HO 144/3577. For O'Brien's return to England, see Pall Mall Gazette (London) 14 May 1923. On the expediting of the Lords' hearing, see The Times (London) 11 May 1923, 5.

${ }^{186}$ In his advice of 30 April 1923, TNA 27/177, HM Giveen, wrote, 'If an adverse decision of the Court of Appeal cannot be tested by an appeal to the House of Lords, the only other method of testing it which occurs to me is to wait for an action to be brought against the Home Secretary and to appeal in that case.' O'Brien did commence proceedings for false imprisonment at the start of May: The Times (London) 2 May 1923, 15.

${ }^{187}$ O'Brien $v$ Secretary of State for Home Affairs [1923] AC 603, where (following Cox v Hakes (1890) 15 App Cas 506) the Lords held that there could be no appeal from the decision of a court to issue the writ. The government had pondered an appeal on the mater of costs, as a way to get the substantive issues raised in the Lords, though they were advised that this would not be possible: opinion of H M Giveen, 30 April 1923, TNA 27/177. The Cabinet noted that the Lords' decision 'left the case in an unsatisfactory position,' since in the lower courts, three judges had 
court. The government's willingness to comply - at the first stage of what might otherwise have been a long, drawn-out process - may have reflected an awareness that it was by now a political impossibility to argue that they had no control. Not only had the government proclaimed its de facto control, but as The Times stated after the Court of Appeal's decision, 'it would be startling indeed if the Courts were to hold that the Executive might defeat the Statutes, and indeed the Common Law, by shipping persons under arrest to a place where the English writ of habeas corpus could not run'.

As a result of the decision, over 100 internees who had been deported to Ireland were released. However, prior to O'Brien's return, plans had already been laid by the two governments for further proceedings to be taken against him and half a dozen others. ${ }^{189}$ As soon as O'Brien left the court which had secured his release from internment, he was rearrested and taken to Bow Street magistrates court on a charge of seditious conspiracy. ${ }^{190}$ By the time the House of Lords handed down the reasons for its judgment in the crown's appeal, O'Brien and Sean McGrath had been convicted and sentenced to two years' imprisonment. ${ }^{191}$ O'Brien's legal challenges may not have secured him his liberty, but, with the aid of political pressure from parliamentarians, they did restrain the government's departures from the rule of law. The Cabinet's immediate response to the Lords' decision was to pass a single bill both to Indemnify the Home Secretary for his actions, and 'to obtain legislative powers for the arrest and internment in Great Britain and Northern Ireland of persons engaged in plots against Ireland or other parts of the Empire'. However, following strong protests from MPs, the latter proposal was dropped from the bill. ${ }^{192}$ The government also had some difficulties with its Indemnity Bill, designed to protect the Home Secretary not only from an action by O'Brien for false imprisonment, but also for the penalties prescribed by section 11 of the Habeas Corpus Act 1679 for those who sent prisoners abroad. ${ }^{193}$ The Labour Party opposed the Indemnity Bill, and criticised the Home Secretary for describing as criminal the activities of men whose trial was still in progress. Criticism was also raised that an Indemnity Bill would remove the internees' right to financial compensation, and this objection was met by the creation of an Irish Deportees Compensation Tribunal, presided over

been for the government and three against: TNA CAB 23/45/26.

188 The Times (London) 10 May 1923.

189 The British wanted him to be arrested immediately on his release from internment on 'a warrant issued in Dublin and backed by a Magistrate here, for offences of seditious conspiracy in Ireland against the Free State'. Letter from JHH to General O'Hagarty 1 May 1923 in TNA HO $144 / 3577$. By contrast, the Irish government hoped 'that in preference to releasing the prisoners the British Govt will decide to bring them to trial': Reported in letter to M Sturgis, 2 May 1923, TNA HO 144/3577.

190 The Times (London) 17 May 1923, 11.

${ }^{191}$ The Times (London) 5 July 1923, 15. For the case, see Foxton, Revolutionary Lawyers (n 119) 370-72.

192 TNA CAB 23/45/26, CAB 23/45/28, The Times (London) 15 May 1923, 14; 18 May 1923, 13.

${ }^{193}$ See Porter Chandler, 'Praemunire and the Habeas Corpus Act considered in connection with the Irish deportations and the case of Ex Parte O'Brien' (1924) 24 Columbia L Rev 273. 
by Atkin LJ. ${ }^{194}$ O'Brien's legal actions were stayed, though he did recover compensation from the committee.

In O'Brien's case, Sir Douglas Hogg argued that the writ should not issue against the Home Secretary, since he had no control over O'Brien 'except insofar as it is given by an agreement entered into between the British Government and the Free State ... and that agreement is not enforceable in any Court of law. ${ }^{195}$ As a matter of law, it was right to say that, at that point, WC Bridgeman had no legal power over the Irishman, but only an agreement that no English court could enforce. However, as in Barnardo, the court was not prepared to treat the question of control as one settled by such legal analysis. It was a factual question, which required the court to be convinced that it was factually impossible to obtain the return of the prisoner. In other words, where the government had disposed of a person in violation of the rule of law, the court was prepared to go to extremes - in effect threaten an attachment against the Home Secretary - if he did not take all the steps he could to obtain the return of the body. At the same time, it was clear that the matter was also deeply political. Without the political pressure from the Labour Party and the media, the government might have held out. But equally, without the Court of Appeal's decision, the political pressure would have had no effect.

\section{Epilogue}

Art O'Brien's case signalled a move by the Court of Appeal away from the executive-minded approach taken both in the wartime detention cases and in the early twentieth century colonial rendition cases we have examined, and the court also took a broad view of the reach of the writ. In this case, it secured the return of a prisoner who had been transferred without lawful authority to another jurisdiction. The decision did not, of course, spell the end of political detentions. Emergency legislation passed at the outbreak of the second world war resulted in the detention of nearly 2,000 detentions of British citizens under Regulation 18B, which conferred power on the Home Secretary to detain anyone he had 'reasonable cause to believe' was 'of hostile origin or associations'. In the context of the war, the highest court reverted to the executive-mindedness it had shown in the Great War, holding in Liversidge $v$ Anderson - in the face of Lord Atkin's famous dissent - that it could not examine the reasons for the detention, but had to accept the Home Secretary's assertion that he had reasonable grounds at face value. ${ }^{196}$

Within the colonial context, very large numbers of political prisoners continued to be detained without trial as struggles for independence intensified in the twentieth century. In many colonies in the post-war period, states of emergency were declared, authorising detention without trial on

${ }^{194}$ See the letter from JW Hall in The Times (London) 11 May 1923, 15; Parl Debs, 5th ser, vol 164, col 859 (28 May 1923). The resulting legislation was the Restoration of Order In Ireland (Indemnity) Act 1923. The tribunal only compensated for actual losses.

${ }^{195}$ Ex p O’Brien (n 129) 369.

${ }^{196}$ Liversidge v Anderson [1942] AC 206, discussed in AWB Simpson, In the Highest Degree Odious: detention without trial in wartime Britain (OUP 1994). In 1980, Lord Diplock expressed the view that the judges in the majority 'were expediently and, at that time, perhaps, excusably wrong': Reg v Inland Revenue Commissioners, ex p Rossminster [1980] AC 952, 1011. 
the model used in wartime Britain. ${ }^{197}$ The number of political detainees able to challenge their detentions remained very small. Only a handful of habeas corpus cases reached courts in London, where they met with mixed results. Where regulations had been clearly worded to authorise the detention or removal of prisoners, the Privy Council upheld the power to detain, and to transfer prisoners from one jurisdiction to another, by tracing the power formally to valid legislative instruments. Thus, in Zabrovsky v General Officer commanding Palestine, it was held that the writ could not be used to challenge the detention by the British military authorities in Eritrea of the applicant's son, who had been detained by the authorities in Palestine and deported to Eritrea. ${ }^{198}$ Distinguishing the decision in O'Brien, the court held that the Palestinian authorities had the power to detain and deport Arie Ben Eliezer under its Emergency Regulations. Although they had no power to order his detention in another jurisdiction, it was pointed out that his detention in Eritrea was by virtue of a proclamation issued by the British military authorities in Eritrea, which the Jerusalem court (and the Privy Council from which the appeal was brought) could not examine. Although the judges were aware of the importance of the writ for the liberty of the subject, they noted how, '[i]n the troublous times of war and in the chaotic post-war conditions', the executive had been given extensive power to interfere with it. ${ }^{199}$ Similarly, in Al Baker $v$ Alford, the Privy Council upheld the transfer to St Helena of political prisoners from Bahrain - a foreign territory in which the crown exercised a jurisdiction under the Foreign Jurisdiction Acts of 1890 and 1913 - after last minute Orders in Council had been issued, to allow an arrangement to be made under the 1869 Colonial Prisoners' Removal Act. $^{200}$ The men were ultimately released, not because any court considered that the colonial legislation was inappropriate for this kind of transfer, but because of a formal slip, when it was revealed that the warrant for the men's removal had been issued before the sanctioning Order in Council had been published. ${ }^{201}$

Although tightly-drafted regulations often limited the power of judges to challenge the legality of

${ }^{197}$ See Simpson (n 16) and B Simpson, 'The Devlin Commission (1959): Colonialism, Emergencies and the Rule of Law' (2002) 22 OJLS 17-52. Where states of emergency were declared, the colonial authorities set up advisory committees, modelled on that used for Reg $18 \mathrm{~B}$ detainees in wartime Britain, to which detainees could appeal.

${ }_{198}$ Zabrovsky v General Officer commanding Palestine [1947] AC 246.

${ }^{199}$ Eliezer Zabrovsky v General Officer commanding Palestine [1947] AC 246, 255. Like Liversidge $v$ Anderson, this case later attracted negative judicial comment: see per Sedley LJ, in Regina (Bancoult) v Secretary of State for Foreign and Commonwealth Affairs (No 2) [2008] QB 365, [52].

${ }^{200}$ Al Baker v Alford [1960] AC 786 (PC).

${ }^{201}$ See the discussion in David Clark and Gerard McCoy, The Most Fundamental Legal Right: Habeas Corpus in the Commonwealth (OUP 2000) 54. If this showed that formalism had its uses, there were also limits to its effectiveness. A formalist approach to the powers of colonial authorities to legislate for detentions was taken by the Privy Council in Madzimbamuto $v$ Lardner-Burke [1969] 1 AC 645, holding a detention order issued by the Southern Rhodesian government after its unilateral declaration of independence to be 'void and of no effect'. However, the decision was ignored by the authorities in Southern Rhodesia, and Madzimbamuto remained in detention. 
detentions, there were also some cases where a less formalist approach could be taken, and detainees were given a remedy using the writ. One such was the case of Eshugbayi Eleko, who was removed from Lagos, where he was paramount chief, by the Governor in $1925 .{ }^{202}$ The latter had power, under the Deposed Chiefs Removal Ordinance of 1917, to remove any 'native chief' who had been removed from office 'by and with the sanction of the Governor', either if 'native law and custom' required it or if he considered it necessary for the peace, order, and good government. Using this legislation, the colonial authorities issued two orders: one sanctioning his deposition - which was said to have been by other members of the ruling house - and another ordering his deportation, on the grounds that native law and custom required it. After a number of unsuccessful habeas corpus applications had been made to courts in Nigeria, the case came on appeal to the Privy Council a second time in March 1931, whose judgment was given by Lord Atkin. The court found for the applicant, in a judgment which was not simply a formal finding that the Governor had acted ultra vires. ${ }^{203}$ Atkin rejected the crown's argument that it was bound to accept as conclusive the Governor's judgment that Eleko had been properly deposed, and that there was a native law or custom requiring his removal. As he explained, the Governor's powers in this matter were simply executive, and "no member of the executive can interfere with the liberty or property of a British subject except on condition that he can support the legality of his action before a court of justice. ${ }^{204} \mathrm{He}$ further rejected the crown's argument that it was the Governor, and not the members of the ruling house, who appointed and removed chiefs. Since such a contention 'may seriously affect the rights of natives in Nigeria', its validity could only be established by examining the constitutional usage in Nigeria. Only by doing so could the court reconcile 'the existence of the suggested powers with the 'rights of the native communities' ${ }^{205}$ Once the case was remitted to Nigeria, the authorities decided to release Eleko. As this case showed, judges did not always favour the executive's powers to detain, and did not always weigh the legality of detention in purely formal terms.

There were also some decisions which took a broad view of the reach of writ. This can be seen from the case of Andrew Mwenya, one of the 61 activists and trade unionists who had been excluded from the Copper Belt in Northern Rhodesia, by virtue of Restriction Orders issued under the Emergency Powers Regulations, $1956 .{ }^{206}$ In 1959, he had sought a writ of habeas corpus against the Colonial Secretary, the Governor of Northern Rhodesia and the District Commissioner of Mporokoso, the place to which he had been restricted, claiming that the restrictions were ultra vires, since the parent Order in Council under which they were issued had

${ }^{202}$ Eshugbayi Eleko v Officer Administering the Government of Nigeria (No 1) [1928] AC 459 (PC) 463. For details of this case, see Patrick Cole, Modern and Traditional Elites in the Politics of Lagos (CUP 1975) ch 5 and Bonny Ibhawoh, Imperial Justice: Africans in Empire's Court (OUP 2013) ch 5.

203 The wording of the Governor's orders did, however, open up space for such a finding; for the order was not worded to indicate that Eleko had been deposed on the Governor's orders, and exiled for the sake of the peace, order, and good government of the colony.

${ }^{204}$ Eshugbayi Eleko v Officer Administering the Government of Nigeria (No 2) [1931] AC 662 (PC) 670 .

205 ibid 672.

206 The names of those excluded were listed in Parl Debs 5th ser, vol 566, col 1113-14. 
not been validly published. Like Sekgoma's case, this was an application made in London for a writ to run to a Protectorate. ${ }^{207}$ The application failed in the Divisional Court, which accepted the crown's objections to the court's jurisdiction to issue the writ. Lord Parker CJ held that the writ could not be issued against the officials in Africa, since it only ran to territories subject to the crown, and could not extend to a 'foreign' territory, such as a Protectorate, even if the person detaining the prisoner was himself a servant of the crown. ${ }^{208} \mathrm{He}$ also held that it could not be issued against the Colonial Secretary in London, since he did not have sufficient control over Mwenya to be subject to the writ. ${ }^{209}$ In taking this view, the court did not explore the question raised in the cases of Barnardo and O'Brien, whether there was evidence that the Colonial Secretary had de facto control, ${ }^{210}$ preferring to focus on the jurisdictional questions which had also occupied the court in Sekgoma's case.

The Court of Appeal however allowed the appeal (paving the way for the case to be heard on its merits $)^{211}$ after deciding that 'if upon a proper investigation of the facts, it appears that the internal governance of Northern Rhodesia is in legal effect indistinguishable from that of a British colony or a country acquired by conquest,' then the writ would run against officials on the Protectorate. ${ }^{212}$ In taking this view, the judges were very alive to the importance of the writ for liberty. As Romer LJ perceived:

The contrary view would result in a subject having no redress at all if he were detained, however unlawfully, in a protectorate which was in substance a colony but which had no effective courts of its own. ... For myself I do not believe that the right of the sovereign to inquire into the liberty of her subjects depends on a narrow distinction between territory which is part of Her Majesty's dominions in substance and territory which has become part of her dominions in fact by a formal act of annexation. ${ }^{213}$

In the event, the court did not have to decide the complex question of whether there was a court with jurisdiction in Northern Rhodesia, or whether the 1939 Order in Council had been validly

${ }^{207}$ There was some debate over whether there was a court of competent jurisdiction in Northern Rhodesia: The Times (London) 13 May 1959, 13.

${ }^{208}$ In taking this view, the court followed the ruling of Kennedy LJ in Ex p Sekgome, regarding the other two judges' countervailing opinion as obiter: Ex p Mwenya [1960] 1 QB 241, 274.

209 According to Lord Parker CJ, his only power in this case derived from his constitutional position as an adviser to the crown: but the fact 'that he can advise and attempt to persuade Her Majesty to cause the body to be brought up does not mean that he has such a control as will enable the writ to issue': Ex p Mwenya (n 208) 280.

${ }^{210}$ See In re Sankoh (2000) 119 ILR 386, [12], where Laws LJ held that 'there is not the whisper of an objective basis for the suggestion that the Secretary of State has now, or had at any time from July 2000 onward, anything amounting to a degree of control over Mr Sankoh such as might justify the issue of a writ of habeas corpus'.

${ }^{211}$ There was some uncertainty about which court should hear this: see GIAD Draper, 'Habeas Corpus and Protectorates - some further reflections' (1960) 76 LQR 211.

${ }^{212}$ Ex parte Mwenya (n 208) 303 (Lord Evershed MR).

213 ibid 305-06. 
issued, for the restriction orders were revoked on 20 October. $^{214}$

The question of the reach of the writ, and how it can be used to challenge the legality of renditions, has been revisited recently by the Supreme Court in Rahmatullah $v$ The Secretary of State for Defence, where the court spent some time considering the cases of Barnardo, Sekgoma, and O'Brien. The case shows how in the contemporary era, where international human rights norms have greater purchase in the jurisprudence of the domestic courts than in the era studied in this article, ${ }^{215}$ courts may take a broader view of questions of legality than was often the case previously, but that similar dilemmas about the issue of control may persist. Yunus Rahmatullah, a Pakistani national, was arrested by British troops in February 2004, in a house in Baghdad. Soon afterwards, he was handed over to the US military, who transferred him to a detention facility at Bagram Air Field in Afghanistan. After six years in detention, the US military concluded in a review that Rahmatullah was not an 'enduring security threat', that his continued detention was not necessary and that he should be transferred to Pakistan for release. He was however kept in custody while the US sought 'appropriate security assurances' from Pakistan that he would not pose a threat once released, and in May 2011 an application was made in London for a writ of habeas corpus to the Secretary of State and the Foreign Secretary to secure his release. ${ }^{216}$ Rahmatullah's initial detention had not been unlawful, nor had it been unlawful (under the Geneva Conventions) for the British to hand him over to the Americans. ${ }^{217}$ However, once it became apparent that his detention was no longer necessary, and that the Americans would not release him, the British came under an obligation - under both international and domestic law - to 'correct the situation' or request his return. ${ }^{218}$

The case raised issues pertaining to the reach of the writ and its capacity to test the legality of the

${ }^{214}$ The Times (London) 27 October 1959, 3.

${ }^{215}$ Although the British ratified the European Convention on Human Rights in 1951, it issued notices in the 1950s that it was derogating from its obligations in colonies where states of emergency had been declared: see AW Brian Simpson, Human Rights and the End of Empire: Britain and the Genesis of the European Convention (OUP 2004) ch 17, esp p 878.

${ }^{216}$ This information is derived from the judgment of Lord Kerr of Tonaghmore in Rahmatullah $v$ Secretary of State for Defence [2012] UKSC 48, [2013] 1 AC 614, [1]-[5], [38]; http://www.reprieve.org.uk/cases/yunusrahmatullah/ (accessed 24 November 2014). For academic comments on the case, see Tatyana Eatwell, 'Selling the pass: habeas corpus, diplomatic relations and the protection of liberty and security of persons detained abroad' (2013) 62 ICLQ 727-39; Hayley J Hooper, 'Shining light on the darkness? Rahmatullah v Secretary of State for Foreign and Commonwealth Affairs and Secretary of State for Defence' (2013) Public L 213-22.

${ }^{217}$ Under the Geneva Conventions, one party can hand over a detainee to another, as long as the receiving party is willing to adhere to the conventions. To comply with these requirements, the British and Americans entered into a Memorandum of Understanding in which the Americans agreed (among other things) to return prisoners 'without delay upon request'.

${ }^{218}$ The relevant articles of the Fourth Geneva Convention relative to the protection of civilians in time of war are Articles 45, 132, and 133. The domestic obligations arose out of the 1957 Geneva Conventions Act. 
detention, as well as to the kinds of questions regarding control which were raised in Barnardo's case and O'Brien's case. Both the Court of Appeal and the Supreme Court accepted that the writ could be used to test the legality of the detention of anyone under the control of the UK government, regardless of whether they were a British national or were being held in any dominion of the crown. ${ }^{219}$ The courts also agreed that the writ could be used, given that Rahmatullah's continued detention had become unlawful, even though his initial detention and rendition had not been so. In doing so, they took a broad view of the power of the writ to test the legality of the detention. Insofar as Rahmatullah had never been illegally in the custody of the British, and that the aim of the litigation was to force the government to comply with its obligations under the Geneva Conventions to seek his return, it might have appeared that a different kind of remedy would have been more suitable than habeas corpus. ${ }^{220}$ However, the court was prepared to grant the remedy by habeas corpus - potentially a more powerful one without getting caught up in technicalities. As Lord Carnwarth and Baroness Hale put it, 'The strength of habeas corpus is its simplicity. ${ }^{221}$ In taking this view, the court took a broader view of the scope of the writ than their predecessors had done in Barnardo v Ford, but one of which the contemporary critics of that judgment might have approved.

When it came to the issue of control, both the Court of Appeal and the Supreme Court rejected the crown's argument that since they had no legal control over Rahmatullah, the writ should not issue, just as similar arguments had been rejected in O'Brien. The Court of Appeal ordered that it should issue, since there was at least uncertainty over whether a request to the Americans to return him would be adhered to. ${ }^{222}$ As a result, the UK authorities wrote a formal letter to the Deputy Assistant Secretary of Defense of the US government, informing them both of the court's decision and their intention to appeal against it, and requesting Rahmatullah's transfer to UK custody in order for him to be released. A reply was sent on 8 February, in which the US authorities explained their procedures for releasing detainees such as Rahmatullah. The letter did not contain any direct refusal to hand him over, and ended with a sentence looking forward 'to discussing this matter further'. Nonetheless, the Court of Appeal held that this letter did clear up any factual ambiguities and that a sufficient return had been made to the writ. In coming to this decision, the court accepted the 'unequivocal evidence' of the recipients of the letter - officials in the Ministry of Defence and the Foreign and Commonwealth Office - 'that in the world of

219 The doubts over this we have seen in Sekgoma's case were removed by cases such as Ex parte Mwenya (n 208) and Re Sankoh (n 210). Contrast the approach taken in the US in $A l$ Maqaleh v Gates 605 F3d 84 (DC Cir 2010).

${ }^{220}$ As Lord Phillips of Worth Matravers pointed out, the question of whether habeas corpus was in fact the right remedy to use in such situations had not been explored in the arguments; and he himself expressed some doubt over whether the remedy should not rather lie 'in judicial review and the doctrine of legitimate expectation': Rahmatullah v Secretary of State for Defence [2012] UKSC 48, [2013] 1 AC 614, [106]. Another alternative remedy might have been mandamus.

${ }^{221}$ They were 'not unduly concerned' by this 'unexplored issue', arguing that the court should not be concerned with 'nice distinctions' which turned on 'different categories of illegality': ibid [121].

${ }^{222}$ Rahmatullah $v$ Secretary of State for Foreign and Commonwealth Affairs [2011] EWHC Civ 1540, [2012] 2 All ER 1290, [2012] 1 WLR 1472, [38]-[39]. 
international relations the letter amounts to a refusal to hand over the applicant'. The court was clearly wary of 'dictating to the $\mathrm{FCO}$ or the $\mathrm{MoD}$ as to how to communicate with a foreign government', but felt that the writ had at least performed 'its minimum function of requiring the UK Government to account for its responsibility for the applicant's detention, and to attempt to get him released'. ${ }^{223}$ In taking this 'narrow' approach to the question of testing the degree of control, the Court of Appeal echoed the sensitivities which judges have long expressed, in seeking to avoid making decisions which would impact on the conduct of foreign policy, an area of executive activity long considered to be non-justiciable. ${ }^{224}$

On this political question, the Supreme Court noted that in issuing the writ, the court was not asking the government to 'make any particular diplomatic move', but only to show why, as a matter of fact, it was impossible to obtain the detainee's release. ${ }^{225}$ They were not treading into territory traditionally seen as not being justiciable. Nonetheless, the majority agreed that the Court of Appeal had been right not to require any further testing of the accuracy of the return, and that the letter had been conclusive. They were clearly not prepared to go as far, in testing the accuracy of the return, as their predecessors had done in Barnardo v Ford. However, two of the justices in the Supreme Court (Carnwarth and Hale) dissented on the finding that the return was adequate, feeling that the court should have gone further in testing the degree of control. ${ }^{226}$ It may be suggested that the dissenters had a good point. The 'minimalist' approach to testing the accuracy of the return certainly contrasts strikingly with the kind of 'maximalist' approach taken in Margaret Aylward's case and that of Dr Barnardo. The judges in those cases were, as has been seen, very keen to ensure that nothing be done to 'baffle' the court in its protection of liberty, and to ensure that the rule of law is complied with. Moreover, as can be seen from the cases of Sekgoma and Zaghlul, the political story told to the courts does not always give the full picture; and that when it comes to matters of liberty, it is often wise to ask more questions.

${ }^{223}$ Rahmatullah $v$ Secretary of State for Foreign and Commonwealth Affairs [2012] EWCA Civ 182, [2012] 1 WLR 1462, [13] and [17].

${ }^{224}$ See $R$ (on the application of Abbasi) $v$ Secretary of State for Foreign and Commonwealth Affairs [2002] EWCA Civ 1598, as well as the dicta in $R v$ Secretary of State for Foreign and Commonwealth Affairs, ex p Pirbhai (1985) 107 ILR 462, 479 and $R v$ Secretary of State for

Foreign and Commonwealth Affairs, ex parte Ferhut Butt (1999) 116 ILR 607, 615.

${ }^{225}$ Rahmatullah v Secretary of State for Defence (n 220) [70].

${ }^{226}$ ibid [129]: 'Where liberty is at stake, it is not the court's job to speculate as to the political sensitivities which might be in play.' 